\title{
Nitrogen input in different chemical forms and levels stimulates soil organic carbon decomposition in a coastal wetland
}

\author{
Wendi Qu ${ }^{\mathrm{a}, \mathrm{b}, \mathrm{c}}$, Guangxuan Han $^{\mathrm{a}, \mathrm{c}, *}$, Franziska Eller ${ }^{\mathrm{d}}$, Baohua Xie ${ }^{\mathrm{a}}$, Jian Wang ${ }^{\mathrm{e}}$, Haitao Wu ${ }^{\mathrm{f}}$, \\ Juanyong $\mathrm{Li}^{\mathrm{a}}$,b,c , Mingliang Zhao ${ }^{\mathrm{a}}$ \\ ${ }^{a}$ CAS Key Laboratory of Coastal Environmental Processes and Ecological Remediation, Yantai Institute of Coastal Zone Research (YIC), Chinese Academy of Sciences \\ (CAS), Shandong Key Laboratory of Coastal Environmental Processes, YICCAS, Yantai, Shandong 264003, PR China \\ ${ }^{\mathrm{b}}$ University of Chinese Academy of Sciences, Beijing 100049, PR China \\ ${ }^{\mathrm{c}}$ Center for Ocean Mega-Science, Chinese Academy of Sciences, 7 Nanhai Road, Qingdao 266071, PR China \\ ${ }^{\mathrm{d}}$ Department of Bioscience, Aquatic Biology, Aarhus University, Ole Worms Alle 1, 8000 Aarhus C, Denmark \\ ${ }^{\mathrm{e}}$ Department of Geography, The Ohio State University, Columbus, OH 43210, USA \\ ${ }^{\mathrm{f}}$ Northeast Institute of Geography and Agroecology, Chinese Academy of Sciences, Changchun 130102, PR China
}

\section{A R T I C L E I N F O}

\section{Keywords:}

Nitrogen input

Soil organic carbon decomposition

Nitrogen chemical forms and levels

Coastal wetland

\begin{abstract}
A B S T R A C T
Nitrogen (N) input significantly regulates soil organic carbon (SOC) storage in N-limited ecosystems. However, the regulatory direction, magnitude, and mechanisms of SOC decomposition under continuous $\mathrm{N}$ input in different chemical forms and levels in coastal wetlands are poorly understood. We investigated the impact of 6-year $\mathrm{N}$ input in a coastal wetland of the Yellow River Delta, examining the effects on plant growth and soil properties for different chemical forms ( $\mathrm{NH}$ : ammonium, NO: nitrate, and $\mathrm{NN}$ : ammonium-nitrate) and levels (5 $\mathrm{g} \mathrm{N} \mathrm{m}^{-2}$ $\mathrm{yr}^{-1}, 10 \mathrm{~g} \mathrm{~N} \mathrm{~m}^{-2} \mathrm{yr}^{-1}$, and $\left.20 \mathrm{~g} \mathrm{~N} \mathrm{~m}^{-2} \mathrm{yr}^{-1}\right)$ at two depths $(0-10 \mathrm{~cm}, 10-20 \mathrm{~cm})$. We also set up an incubation experiment with $\mathrm{N}$-treated soil to investigate SOC decomposition under different treatments. Six-year $\mathrm{N}$ input led to overall increases in the soil nutrients (i.e., total $\mathrm{N}$, ammonium- $\mathrm{N}\left(\mathrm{NH}_{4}{ }^{+}-\mathrm{N}\right)$, and nitrite- $\mathrm{N}\left(\mathrm{NO}_{3}{ }^{-} \mathrm{N}\right)$ ), stimulation of plant growth (i.e., plant biomass, height, and density), enhancement of soil C storage (i.e., total carbon, SOC, dissolved organic carbon, and microbial biomass carbon), and decreases in the electrical conductivity (EC). The incubation experiment revealed that $\mathrm{N}$ input-induced SOC decomposition stimulation is $\mathrm{N}$ form dependent; NO input was the strongest stimulator of decomposition, when compared to NH and NN input. The stimulation differences among the dominant-form $\mathrm{N}$ inputs increased with increasing $\mathrm{N}$ supply levels. Structural equation modeling (SEM) analysis indicated that the stimulation of SOC decomposition by $\mathrm{N}$ input was associated with $\mathrm{N}$-related changes in the soil nutrients, vegetation, soil $\mathrm{C}$ storage, and soil environment. Together, these results aid the evaluation of soil $\mathrm{C}$ cycling under future $\mathrm{N}$ deposition scenarios in coastal wetlands.
\end{abstract}

\section{Introduction}

Anthropogenic activities (e.g., agricultural fertilization and fossil fuel combustion) have remarkably accelerated reactive nitrogen $(\mathrm{N})$ deposition over the last century (Galloway et al., 2008), which has affected the soil physicochemical properties and soil carbon (C) dynamics (Manning et al., 2008; Mo et al., 2008; Allison et al., 2009; Tao et al., 2013; Liu et al., 2016). Coastal wetlands are one of the most productive ecosystems on Earth, serving as natural "blue carbon" sinks due to their low rate of soil organic carbon (SOC) decomposition (Ferrati et al., 2005; Bridgham et al., 2006). The effects of $\mathrm{N}$ input on plant growth, microbial activities, and soil C transformation have been widely studied in various ecosystems, such as forests, croplands, and grasslands (Reay et al., 2008; Reich and Hobbie, 2013; Zhou et al., 2014; Wang et al., 2018). However, the effects of $\mathrm{N}$ input on SOC decomposition in coastal wetlands remain largely unexplored. Thus, experimental studies are required to investigate the underlying mechanisms of increasing $\mathrm{N}$ deposition and $\mathrm{C}$ dynamics in this ecologically important ecosystem.

The effects of $\mathrm{N}$ input on the terrestrial $\mathrm{C}$ cycle have been investigated in numerous field studies and laboratory experiments (Vitousek, 1982; Magill and Aber, 1998; Janssens et al., 2010; Neff

\footnotetext{
* Corresponding author at: CAS Key Laboratory of Coastal Environmental Processes and Ecological Remediation, Yantai Institute of Coastal Zone Research (YIC), Chinese Academy of Sciences (CAS), Shandong Key Laboratory of Coastal Environmental Processes, YICCAS, Yantai, Shandong 264003, PR China.

E-mail address: gxhan@yic.ac.cn (G. Han).
} 

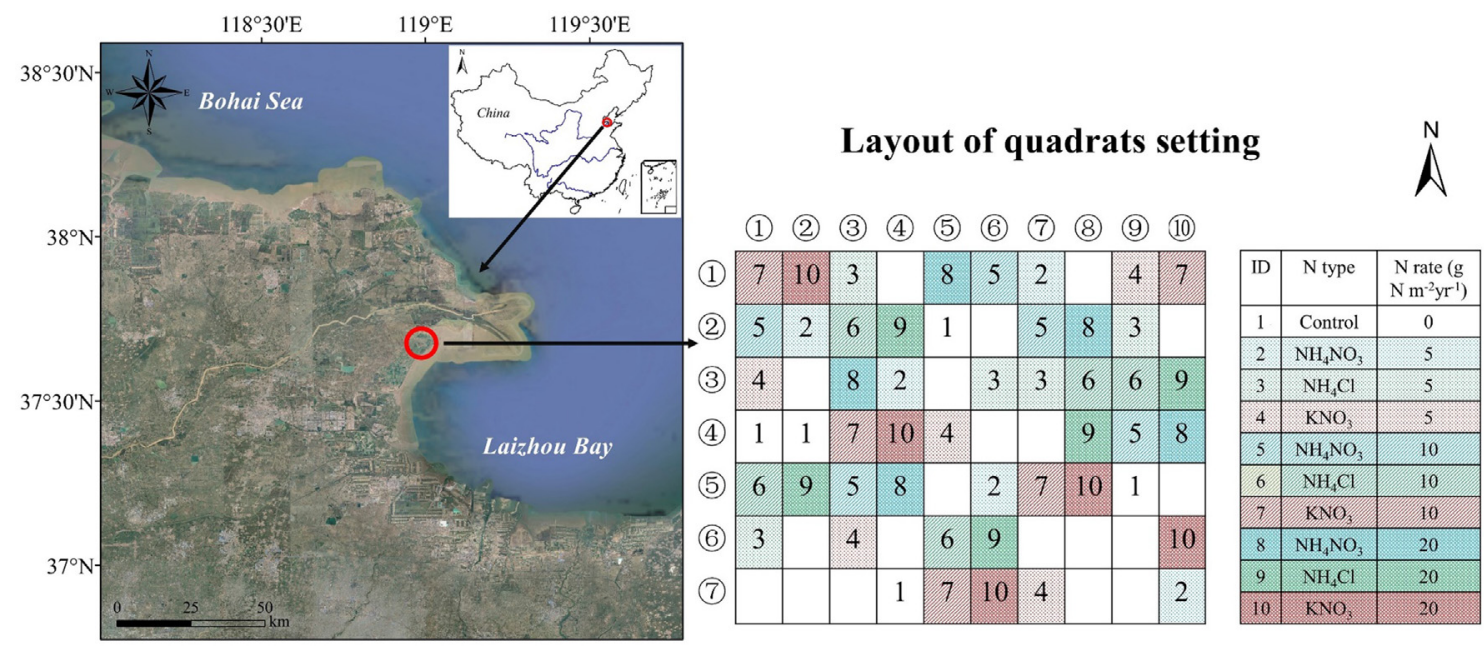

Fig. 1. Location and layout of the experimental plots used to simulate nitrogen deposition.

et al., 2002), yielding inconsistent results. Some studies have reported stimulating effects of $\mathrm{N}$ addition on SOC decomposition, primarily due to improved $\mathrm{N}$ availability and enhanced soil $\mathrm{C}$ content (Knorr et al., 2005; Tu et al., 2013). Suppressive effects of long-term $\mathrm{N}$ addition on SOC decomposition have also been reported, mainly due to lower $\mathrm{pH}$ and decreased microbial abundance, activity, and respiration (Mo et al., 2008; Wang et al., 2017). Ammonium- $\mathrm{N}$ and nitrite-N (henceforth, $\mathrm{NH}_{4}{ }^{+}-\mathrm{N}$ and $\mathrm{NO}_{3}{ }^{-}-\mathrm{N}$, respectively) are ecosystem-dependent inorganic $\mathrm{N}$ chemical forms in the soil. For example, $\mathrm{NH}_{4}{ }^{+}-\mathrm{N}$ levels are generally lower than $\mathrm{NO}_{3}{ }^{-}-\mathrm{N}$ in forests, grasslands, and shrublands, but not in alpine meadows (Song et al., 2018). Fertilization increases the availability of soil nutrients but also shifts the chemical forms and levels of available N (Krupa, 2003; Neff et al., 2002). N input underlies variations in the soil microbial composition and available carbon (McKane et al., 2002; Song et al., 2018), so the impact on SOC decomposition can be explained by ecosystem processes and environmental factors affecting the quality of the organic matter (i.e., the lignin content, C:N ratio, soil $\mathrm{pH}$, nutrient availability, and ecosystem types). For instance, in high-quality litter with a low C:N ratio, SOC decomposition is often accelerated by $\mathrm{N}$ input, due to higher microbial energy savings from increased N availability (Sjoberg et al., 2004; Knorr et al., 2005; Min et al., 2011). Previous research found that microbes prefer $\mathrm{NH}_{4}{ }^{+}-\mathrm{N}$ over $\mathrm{NO}_{3}{ }^{-}-\mathrm{N}$ because of lower energy costs during assimilation (Puri and Ashman 1999). However, if $\mathrm{N}$ fertilization exceeds the ecosystemdependent threshold, plant biomass productivity and/or plant species diversity will stabilize or even decline, due to changes in the soil properties (e.g., acidification) (Roem and Berendse, 2000; Evans et al., 2008). Increased acidification and osmotic pressure from long-term $\mathrm{N}$ input may also have negative impacts on the microbial activities of fungal groups (Treseder, 2008). Thus, $\mathrm{N}$ deposition is a driving force that can regulate plant growth, soil $\mathrm{C}$ storage, and microbial activities. To date, the feedback processes of $\mathrm{N}$ input, vegetation, and soil properties in coastal wetlands are unresolved, and the effects of continuous $\mathrm{N}$ input (in different chemical forms and levels) on SOC decomposition are unclear.

Ecosystem services contribute to human welfare, and the integrity of coastal ecosystems is crucial for coastal protection, erosion, flooding control, fisheries, and recreation (Costanza et al., 1997; Barbier et al., 2011). Coastal wetlands contain large carbon stocks, stabilize sediments, retain nutrients, and deposit particles, and have been thoroughly studied for the impacts of climate change and sea-level rise (Chambers et al., 2013; Meng et al., 2017). Evidence for the effects of $\mathrm{N}$ input on coastal wetlands, especially involving SOC dynamics, is limited, despite their vulnerability to environmental and anthropogenic changes. The coastal wetlands of the Yellow River Delta (YRD), located at the interface of the terrestrial and ocean ecosystems, contribute greatly to local C sequestration (Han et al., 2018). Under short-term $\mathrm{N}$ addition, $\mathrm{NH}_{4}{ }^{+}-\mathrm{N}$ and $\mathrm{NO}_{3}{ }^{-}-\mathrm{N}$ accelerated SOC decomposition and stimulated carbon dioxide $\left(\mathrm{CO}_{2}\right)$ emissions in the coastal wetlands (Tao et al., 2013; Tao et al., 2018). The soil saline-alkaline stress of different ecosystems also affects the ecosystem's sensitivity to $\mathrm{N}$ input and plant diversity (Gao et al., 2019). However, the links between $\mathrm{N}$ input (in different chemical forms and levels) and the vegetation, soil C storage, soil environment, and SOC decomposition of coastal wetlands have received relatively little attention. Most studies have focused on the relationships between the different levels or chemical forms of $\mathrm{N}$ input and SOC decomposition, separately (Lugato et al., 2006; Gerdol et al., 2008; Poffenbarger et al., 2018). It is still unclear if increases in different chemical forms of $\mathrm{N}$ input affect SOC decomposition. We hypothesize that the responses of SOC decomposition to continuous $\mathrm{N}$ input in different chemical forms are regulated by the corresponding input levels, largely through N-related changes in the vegetation status, soil $\mathrm{C}$ storage, and soil environment. To test our hypothesis, we added $\mathrm{NH}_{4}{ }^{+}-\mathrm{N}$ and $\mathrm{NO}_{3}{ }^{-}-\mathrm{N}$ in different forms and levels to experimental mesocosms in the YRD for 6 years, investigating the impacts of continuous $\mathrm{N}$ input on the vegetation and soil properties. We also set up a 40-day soil incubation experiment to quantify SOC decomposition by measuring $\mathrm{CO}_{2}$ and methane $\left(\mathrm{CH}_{4}\right)$ under different $\mathrm{N}$ treatments. The main objectives were (i) to investigate changes in the vegetation and soil properties in a coastal wetland after 6 years of $\mathrm{N}$ input, (ii) to quantify the rate of SOC decomposition under various $\mathrm{N}$ addition treatments, and (iii) to understand how $\mathrm{N}$ input in different chemical forms accelerates SOC decomposition and the role of $\mathrm{N}$ input levels in regulating the stimulation effects.

\section{Materials and methods}

\subsection{Nitrogen fertilization experiment}

The experiment was established in the coastal wetland of the Yellow River Delta Ecological Research Station of Coastal Wetlands, Chinese Academy of Sciences $\left(37^{\circ} 36^{\prime} \mathrm{N}, 118^{\circ} 57^{\prime} \mathrm{E}\right)$, in northeast Shandong Province, China (Fig. 1). In most coastal wetlands of the YRD, the groundwater level ranges from 1 to $3 \mathrm{~m}$, with high salinity due to land-ocean interactions (Han et al., 2015). High evaporation transports soluble salt to the soil surface, extending saline-alkaline soils in the area (Zhang et al., 2011). The YRD coastal wetlands have a typical warm semi-humid continental monsoon climate, with a moderate temperature (annual average: $12.9{ }^{\circ} \mathrm{C}$ ) and adequate precipitation (annual average: $560 \mathrm{~mm}$ ) (Han et al., 2018), and the dominate plant types are 
Phragmites australis and Suaeda salsa (Cui et al., 2009). The canopy height can reach $1.7 \mathrm{~m}$ in the growing season, with a canopy closure vegetation index ranging from 0.3 to 0.8 (Han et al., 2015). The $\mathrm{N}$ deposition rate in the YRD during the growing season (May to November) is nearly $2.26 \mathrm{~g} \mathrm{~m}^{-2}$, and $\mathrm{NO}_{3}{ }^{-}-\mathrm{N}$ and $\mathrm{NH}_{4}{ }^{+}-\mathrm{N}$ are the main $\mathrm{N}$ chemical forms of dry and wet deposition, respectively (Guan et al., 2019).

The mesocosm experiment began in May 2012 with 50 quadrats $(4 \mathrm{~m} \times 6 \mathrm{~m})$ in a Phragmites-dominated flat. To account for the horizontal movement and loss of additional $\mathrm{N}$, the quadrats were approximately $1 \mathrm{~m}$ apart and separated from the surrounding vegetation. The experiment consisted of nine $\mathrm{N}$ input treatments (3 chemical forms $\times 3$ levels) and a control group (CG) without any fertilizer addition. Each treatment was applied to 5 replicate quadrats (Fig. 1). The chemical $\mathrm{N}$ forms were ammonium- $\mathrm{N}(\mathrm{NH})$, nitrate- $\mathrm{N}(\mathrm{NO})$, and ammonium plus nitrate- $\mathrm{N}$ (NN) from ammonium chloride $\left(\mathrm{NH}_{4} \mathrm{Cl}\right)$, potassium nitrate $\left(\mathrm{KNO}_{3}\right)$, and ammonium nitrate $\left(\mathrm{NH}_{4} \mathrm{NO}_{3}\right)$, respectively. The $\mathrm{N}$ treatment levels were set at $5 \mathrm{~g} \mathrm{~N} \mathrm{~m}^{-2} \mathrm{yr}^{-1}$ (low input, 5), $10 \mathrm{~g} \mathrm{~N} \mathrm{~m}^{-2} \mathrm{yr}^{-1}$ (medium input, 10) and $20 \mathrm{~g} \mathrm{~N} \mathrm{~m}^{-2} \mathrm{yr}^{-1}$ (high input, 20 ), to simulate natural and extreme levels of $\mathrm{N}$ deposition (Yu et al., 2014; Guan et al., 2019). The fertilizer was dissolved in $1.2 \mathrm{~L}$ of deionized water, with different concentrations for each $\mathrm{N}$ treatment (Table S1). We applied fertilizer to each quadrat evenly by a sprayer once per month for 66 months. The fertilizer was sprayed directly onto the soil or plant root to decrease interception by the plant branches and leaves. The method we applied is to simulate atmospheric nitrogen deposition, and low interception by branches and leaves could be reasonable ( $\mathrm{Tu}$ et al., 2013, Wang et al., 2019a, 2019b).

\subsection{Sampling and measurement of the plant traits}

The vegetation and soil were sampled at the end of the growing season in October 2018. We randomly selected five sub-quadrats $(1 \mathrm{~m} \times 1 \mathrm{~m})$ in each quadrat and collected all of the vegetation and soil. We recorded the density and height of Phragmites australis (common reed), the dominant plant in all sub-quadrats. Plant biomass was determined as the total above- (shoots) and below-ground (roots) biomass of $P$. australis. The plant samples were stored in hard envelopes and oven-dried at $80{ }^{\circ} \mathrm{C}$ for $48 \mathrm{~h}$ to quantify the biomass $\left(\mathrm{g} \mathrm{m}^{-2}\right)$ in the laboratory.

\subsection{Soil collection and analyses}

Three unsubmerged soil samples from two soil layers (topsoil: 0-10 cm, subsoil: $10-20 \mathrm{~cm}$ ) were randomly collected from each quadrat using a soil drill. The single-ring infiltration method (using a $7 \mathrm{~cm}$ diameter infiltrometer) was used to measure the maximum waterholding capacity. After removing the detritus, the soil samples were packed and sealed in soil bags until analysis in the laboratory. Partial soil samples from each $\mathrm{N}$ treatment were kept in a refrigerator $\left(4{ }^{\circ} \mathrm{C}\right)$ until analysis of the soil microbial biomass carbon (MBC). After airdrying, the soil samples were sieved through a $<2 \mathrm{~mm}$ mesh for homogenization and stored at room temperature. The above-mentioned approach may have affected the microbial biomass and activity, but the impact of soil heterogeneity can be minimized (Qu et al., 2019).

The sample was air-dried, crushed, and divided into 2 subsamples. One subsample was sieved through a $2 \mathrm{~mm}$ mesh and tested for soil $\mathrm{pH}$, electrical conductivity (EC), $\mathrm{NH}_{4}{ }^{+}-\mathrm{N}$, and $\mathrm{NO}_{3}{ }^{-}-\mathrm{N}$. The other subsample was crushed and sieved through a $0.15 \mathrm{~mm}$ mesh to measure the total C (TC), total N (TN), SOC, and soil dissolved organic carbon (DOC). TC and TN were directly analyzed on an elemental analyzer (Vario MACRO cube, Elementar Analysensysteme, Germany). For SOC, the soil samples were pretreated with hydrochloric acid ( $\mathrm{HCl}, 1 \mathrm{~mol} / \mathrm{L})$ to remove total inorganic carbon, and then analyzed on the elemental analyzer. The soil $\mathrm{pH}$ was measured with a portable $\mathrm{pH}$ meter in a 1:5 $(\mathrm{w} / \mathrm{v})$ soil:water suspension potentiometrically, and EC was measured via a portable conductivity meter. To determine the levels of $\mathrm{NH}_{4}{ }^{+}-\mathrm{N}$ and $\mathrm{NO}_{3}{ }^{-}-\mathrm{N}, 3 \mathrm{~g}$ of soil (dry mass) was extracted in $15 \mathrm{~mL}$ of $2 \mathrm{M}$ potassium chloride $(\mathrm{KCl})$ solution, followed by measurement on a continuous flow analyzer (AutoAnalyzer III, Seal, Germany) (Robertson et al., 1999). Before measuring the soil dissolved organic carbon (DOC), deionized water and incubated soil were mixed at a ratio of 1:5 and shaken for $1 \mathrm{~h}$. The mixture was centrifuged at $6000 \mathrm{rpm}$ for $25 \mathrm{~min}$, followed by $0.45 \mu \mathrm{m}$ vacuum filtration (Mavi and Marschner, 2012). Soil DOC was measured on a Shimadzu TOC analyzer (TOC-VCPH). MBC was measured by the chloroform-fumigation extraction method (Brookes et al., 1985), and the Shimadzu TOC analyzer (TOC-VCPH) was used for the $\mathrm{MBC}$ analyses. The characteristics of the soil samples, including TC, TN, SOC, DOC, MBC, pH, EC, $\mathrm{NH}_{4}{ }^{+}, \mathrm{NO}_{3}{ }^{-}$, and the C:N ratio, are shown in Tables S2 (topsoil) and S3 (subsoil).

\subsection{Microcosm soil incubation for $M B C$ analyses}

We prepared sixteen $1 \mathrm{~L}$ jars per treatment combination for each soil layer, plus four additional blank controls (324 jars in total). We added $100 \mathrm{~g}$ of dry soil to each jar and adjusted the soil moisture to $60 \%$ of the maximum soil water-holding capacity by adding deionized water every other day. All 324 sample jars were incubated for 40 days at $25 \pm 2{ }^{\circ} \mathrm{C}$ (Marton et al. 2012; Fang et al. 2019), using an air conditioning to control thermostat and applying air thermometer to monitor the lab temperature.

We divided the incubation period into 4 stages $(10,20,30$, and 40 days) to analyze the temporal patterns of microbial biomass. Four jars with soil and one blank were analyzed at each stage. We excluded MBC on day 1 because the initial water additions to stabilize the soil moisture may have caused an unstable priming effect.

\section{5. $\mathrm{CO}_{2}$ and $\mathrm{CH}_{4}$ efflux and SOC decomposition in the microcosm incubated soil}

The rates of $\mathrm{CO}_{2}$ and $\mathrm{CH}_{4}$ emission in the incubated jars were measured once every two days, and every jar was fitted with an airtight wooden cork with a long needle and a three-way-valve for $24 \mathrm{~h}$ before gas sampling. The collected gas was measured by gas chromatography (Agilent GC-7890, USA). Five empty jars were used as background levels to compare gas production (Liu et al., 2017).

We considered the total rates of $\mathrm{CH}_{4}-\mathrm{C}$ and $\mathrm{CO}_{2}-\mathrm{C}$ emissions as the rate of SOC decomposition (SOCD), calculated as:

$\sum_{\mathrm{t}=\mathrm{d} 1}^{\mathrm{d} 2} \mathrm{SOCD}=\sum_{\mathrm{t}=\mathrm{d} 1}^{\mathrm{d} 2} \mathrm{CH} 4-\mathrm{C}+\sum_{\mathrm{t}=\mathrm{d} 1}^{\mathrm{d} 2} \mathrm{CO} 2-\mathrm{C}$

where $d 1$ and $d 2$ represent the start and end days of the incubation phases, respectively.

\subsection{Statistical analyses}

Two-way and one-way analyses of variance (ANOVA) were conducted in IBM SPSS Statistics 23. We used a two-way ANOVA to assess differences in the soil properties, using the $\mathrm{N}$ levels, $\mathrm{N}$ chemical forms, and their interactions as the fixed effects. One-way ANOVA was applied to assess the statistical differences in the soil properties, plant biomass, height, and density, and SOC decomposition. The differences were significant when $p<0.05$. Pearson correlation analysis was used to calculate the correlations between plant biomass, soil properties, and SOC decomposition.

Structural equation modeling (SEM) allows testing of the indirect links between $\mathrm{N}$ input and SOC decomposition. In this study, we assume that $\mathrm{N}$ input stimulates SOC decomposition via effects on the soil nutrients, vegetation, soil C storage, and soil environment. Pearson correlation analysis indicated that all of the variables were significantly correlated with SOC decomposition, so all were included in the SEM. To 
Table 1

Repeated measures analysis of variance for properties of topsoil $(0-10 \mathrm{~cm})$ and subsoil $(10-20 \mathrm{~cm})$ using supply level, supply chemical forms and interactions as fixed effects.

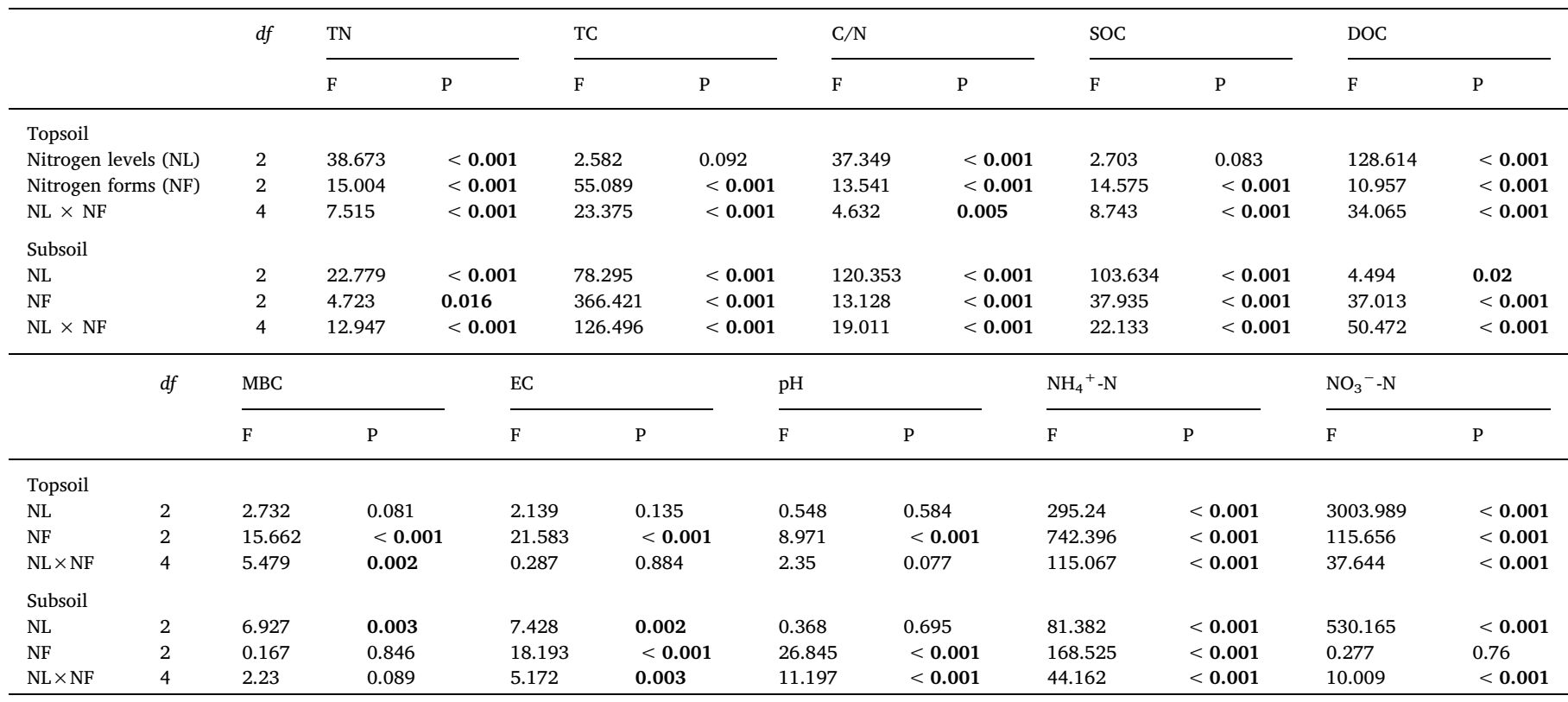

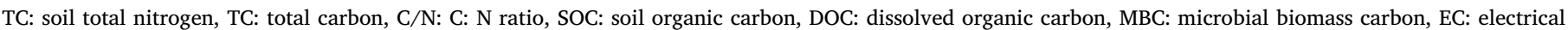
conductivity, $\mathrm{NH}_{4}{ }^{+}-\mathrm{N}$ : ammonium, $\mathrm{NO}_{3}{ }^{-}-\mathrm{N}$ : nitrate. Significant P-values marked in bold $(p<0.05)$.

evaluate the SEM fit, we used the standardized root mean square residual (SRMR), the chi-square to degrees of freedom ratio $\left(\chi^{2} / \mathrm{df}\right)$, and normed fit index (NFI) (Hair et al., 2017). The sample size was lower than 100 , so the partial least square (PLS) method was used to predict complex predictive path models (Wong, 2013). The SEM was conducted in SmartPLS 3.2.8, a software for PLS-SEM (www.smartpls.com).

\section{Results}

\subsection{Impacts of 6-year $N$ input on soil properties and plant growth}

The effects of the $\mathrm{N}$ levels, $\mathrm{N}$ chemical forms, and $\mathrm{N}$ levels $\times \mathrm{N}$ chemical forms on the soil C pools (i.e., total C, SOC, and DOC), total N, $\mathrm{NH}_{4}{ }^{+}-\mathrm{N}, \mathrm{NO}_{3}{ }^{-}-\mathrm{N}$, and EC were all highly significant $(p<0.05)$ (Table 1). The 6-year $\mathrm{N}$ input of different chemical forms and levels significantly increased the soil $\mathrm{N}$ contents, with higher soil total $\mathrm{N}$ (91.5\%), $\mathrm{NH}_{4}{ }^{+}-\mathrm{N}(277.9 \%)$, and $\mathrm{NO}_{3}{ }^{-}-\mathrm{N}(19.7 \%) . \mathrm{N}$ input also significantly enhanced the soil C pools, with $6.6 \%, 15.1 \%$, and $228.8 \%$ increases in total $\mathrm{C}, \mathrm{SOC}$, and $\mathrm{MBC}$, respectively. A lower C:N ratio $(41.2 \%)$ and EC $(21.1 \%)$ were observed in the topsoil and subsoil (Tables S2 and S3). Soil total C, SOC, and MBC in the NO treatments were generally higher than in the NH- and NN-treated soil.

Plant biomass, height, and density were used as indicators of the plant growth response to $\mathrm{N}$ input in different chemical forms and levels. The $\mathrm{N}$ fertilizer generally stimulated plant growth, with $17.6 \%, 20.9 \%$, and $16.4 \%$ increases in plant biomass, height, and density, respectively (Fig. 2). For the NN and NO treatments, the stimulating effects on plant growth tended to increase with increasing $\mathrm{N}$ levels. However, NN input had a neutralizing effect on plant biomass and density. The differences in plant biomass among the dominant-forms of $\mathrm{N}$ increased with increasing $\mathrm{N}$ levels ( $\mathrm{NO}>\mathrm{NH}>\mathrm{NN}$ ).

\subsection{Impacts of $\mathrm{N}$ input on $\mathrm{CO}_{2}$ and $\mathrm{CH}_{4}$ emissions and $\mathrm{SOC}$ decomposition}

The cumulative $\mathrm{CO}_{2}$ emissions over the 40-day incubation period were linear in all of the treatments (Fig. 3). In general, the $\mathrm{CO}_{2}$ emissions from the topsoil were significantly higher than the subsoil $(p<0.05)$, and the highest emissions were observed in the NO treatments of both soil layers. There were no differences in the $\mathrm{CH}_{4}$ emissions, and the cumulative $\mathrm{CH}_{4}$ emissions tended to decrease during the incubation period (Fig. 4).

The SOC decomposition rate was determined by the total rates of $\mathrm{CO}_{2}$ and $\mathrm{CH}_{4}$ emissions in each treatment. During the 40-day incubation period, the N-treated soil had a higher rate of SOC decomposition, with an average enhancement of $41.6 \%$ and $37.7 \%$ in the topsoil and subsoil, respectively (Fig. 5). The NO-treated soil showed stronger stimulation of SOC decomposition relative to the NN- and NH-treated soils. The stimulation differences of SOC decomposition among 3-form $\mathrm{N}$ input generally increased with increasing input levels for two layers of incubated soils ( $\mathrm{NO}>\mathrm{NH}>\mathrm{NN}$ ).

\subsection{Linking $N$-related soil properties to SOC decomposition}

Pearson correlation analysis revealed significant correlations between the plant biomass, soil properties, and SOC decomposition (Table 2). For example, the rate of SOC decomposition was positively correlated with $\mathrm{MBC}$, total $\mathrm{C}$, $\mathrm{SOC}$, total $\mathrm{N}_{\mathrm{NO}_{3}}{ }^{-} \mathrm{-N}$, soil $\mathrm{pH}$, and plant biomass, but negatively correlated with EC. MBC and SOC had significant positive correlations with total $\mathrm{N} \mathrm{NO}_{3}{ }^{-} \mathrm{N}$, and plant biomass, and negative correlations with $\mathrm{NH}_{4}{ }^{+}-\mathrm{N}$ and EC $(p<0.05)$.

SEM analysis was used to explore the underlying mechanisms of $\mathrm{N}$ input, soil nutrients, vegetation, soil C storage, soil environment, and SOC decomposition (Fig. 6). The significance criteria of the fitted model were met, with SRMR, $\chi^{2} / \mathrm{df}$, and NFI of $0.077,2.170$, and 0.925 , respectively. The final model explained $22.2 \%$ of the variance for soil nutrients, $61.1 \%$ for vegetation, $56.8 \%$ for soil C storage, $32.4 \%$ for soil environment, and $57.1 \%$ for SOC decomposition. The soil nutrients (total $\mathrm{N}, \mathrm{NH}_{4}{ }^{+}$, and $\mathrm{NO}_{3}{ }^{-}$) and vegetation (plant biomass, height, and density) were positively driven by $\mathrm{N}$ input and positively associated with soil C storage (total C, SOC, DOC, and MBC), but negatively related to the soil environment ( $\mathrm{pH}$ and EC). Soil $\mathrm{C}$ storage had a significant positive impact on SOC decomposition $(p<0.001)$, while the soil environment had a negative influence on SOC decomposition $(p<0.05)$. 

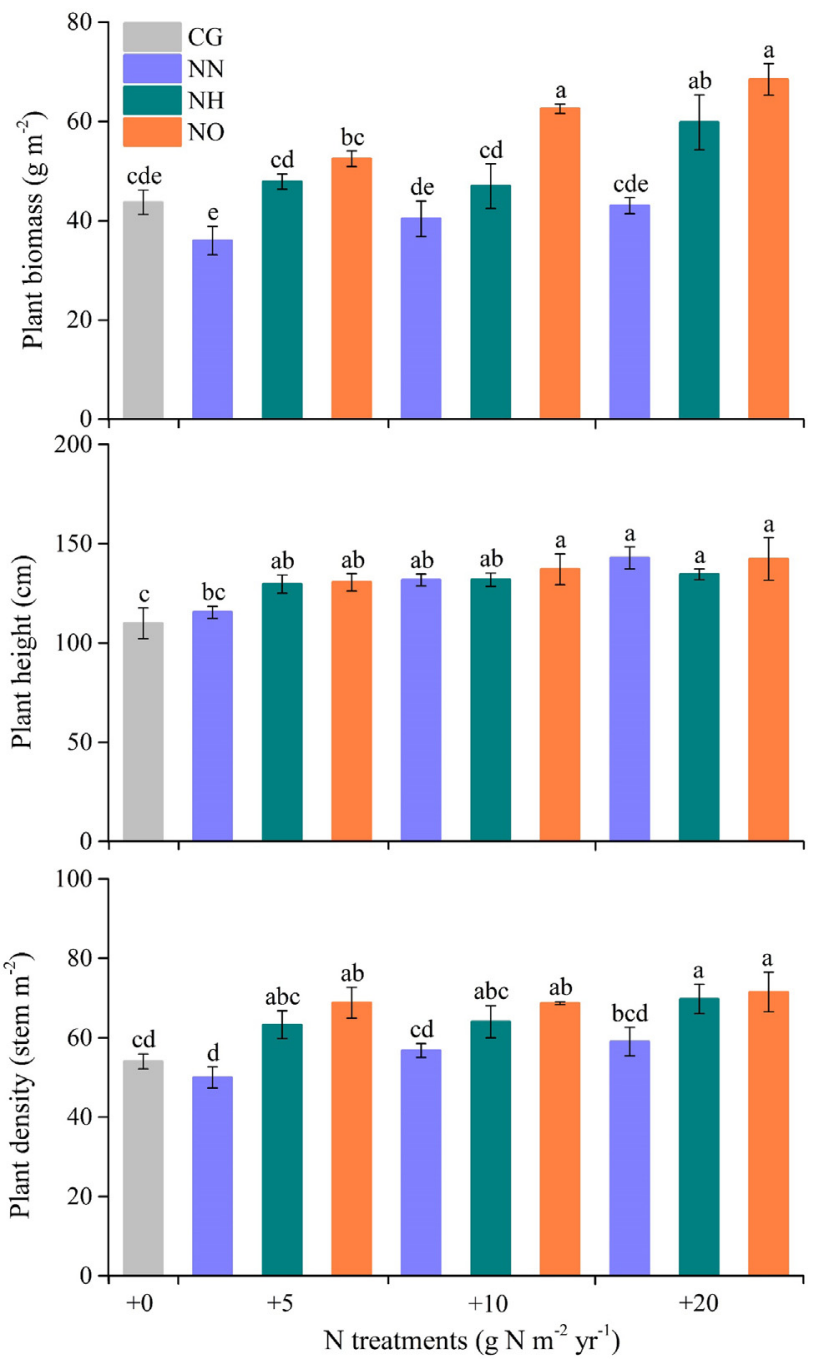

Fig. 2. Effects of nitrogen $(\mathrm{N})$ input on the plant biomass, height and density of Phragmites australis in a coastal wetland of Yellow River Delta. Different lower case letters represent a highly significant difference $(p<0.05)$. CG, NO, NH and $\mathrm{NN}$ represent control group, adding $\mathrm{KNO}_{3}, \mathrm{NH}_{4} \mathrm{Cl}$ and $\mathrm{NH}_{4} \mathrm{NO}_{3}$, respectively. $+0,+5,+10$ and +20 represent no $\mathrm{N}$ input, adding 5, 10 and $20 \mathrm{~g} \mathrm{~N} \mathrm{~m}^{-2} \mathrm{yr}^{-1}$, respectively.

\subsection{Linking $M B C$ variation to SOC decomposition}

The MBC for both soil layers tended to decline across the incubation period (days 10, 20,30, and 40). The N-treated soil samples had a higher average $\mathrm{MBC}$, compared to the CG samples, and the highest MBC was observed in NO-treated soil $(p<0.05)$ (Fig. 7). Significant positive correlations between SOC, MBC, and the rate of SOC decomposition were also observed, with an overall coefficient (r) of 0.65 and 0.69 , respectively (Fig. 8).

\section{Discussion}

\section{1. $N$-related changes in the soil properties and plant growth}

Soil properties play a key role in soil $\mathrm{C}$ accumulation and transformation (Sims et al., 2012; Freschet et al., 2013). In this study, continuous $\mathrm{N}$ input in different chemical forms and levels significantly altered the soil properties (Tables S2 and S3). There was a negative correlation between EC and plant biomass (Table 2, $p<0.05$ ), indicating that $\mathrm{N}$-induced plant growth reduced the soil evaporation and increased the soil water content, indirectly decreasing soil EC (Qu et al.,
2019; Shaygan et al., 2018). Previous studies reported that long-term N input negatively affected soil microbial activities and biomass through increased acidification and osmotic pressure from the oxidation of $\mathrm{NH}_{4}{ }^{+}$to $\mathrm{NO}_{3}{ }^{-}$(Evans et al., 2008; Treseder, 2008). We observed stable $\mathrm{pH}$ under $\mathrm{N}$ input in the topsoil, higher $\mathrm{pH}$ in the subsoil with the NO and $\mathrm{NH}$ treatments, and lower $\mathrm{pH}$ in the $\mathrm{NN}$ soil $(p<0.05)$. The significant positive correlation between $\mathrm{pH}$ and MBC (Table 2) may explain the MBC differences in the N-treated soils, which is consistent with previous studies reporting positive effects of increased soil $\mathrm{pH}$ on the microorganisms (i.e., ammonia-oxidizing bacteria) (Nicol et al., 2008; Ying et al., 2017). Our study also demonstrated that short-term $\mathrm{N}$ input cannot accurately predict the effects of long-term $\mathrm{N}$ deposition on soil microbial biomass and the soil environment (Wang et al., 2019a, 2019b). Evidence suggests that $\mathrm{N}$ input alleviates the $\mathrm{N}$ limitations of soil microorganisms and stimulates soil enzyme (urease) activity in the coastal wetlands of the YRD (Guan et al., 2019). In this study, N input generally increased the microbial biomass; we observed significant positive correlations between microbial biomass and soil total $\mathrm{N}$, $\mathrm{NO}_{3}-\mathrm{N}$, and MBC (Table 2). Therefore, soil salinization and nutrient limitations in the YRD coastal wetlands may be alleviated by $\mathrm{N}$ input, which influences the soil microbial population, composition, and community structure (Zhou et al., 2020).

$\mathrm{N}$ input positively affects plant growth and soil $\mathrm{C}$ storage in nutrient-poor ecosystems (van Der Heijden et al., 2008; Bolinder et al., 2010). In this study, plant growth, soil C storage, and microbial biomass were stimulated in the NO-treated soil, supporting the significant positive correlations between plant biomass, SOC, and MBC (Table 2). Higher levels of $\mathrm{NO}$ and $\mathrm{NH}$ input resulted in greater plant biomass, height, and density. However, neutralizing effects on plant growth were observed in the NN-treated soil (Fig. 2), suggesting that the fertilization effect is $\mathrm{N}$-form dependent in ecosystems where plant growth is limited by the soil nutrients (Tian et al., 2019).

\subsection{The response of SOC decomposition to $N$-related changes}

Previous studies reported contradictory effects of $\mathrm{N}$ input on SOC decomposition via fluxes in the $\mathrm{CO}_{2}$ and $\mathrm{CH}_{4}$ emission rates (Neff et al., 2002; Janssens et al., 2010; Tu et al., 2013; Wang et al., 2017; Fang et al., 2019). Our study is consistent with prior results; both $\mathrm{NH}_{4}{ }^{+}-\mathrm{N}$ and $\mathrm{NO}_{3}{ }^{-}-\mathrm{N}$ stimulated SOC decomposition in the YRD coastal wetlands (Tao et al., 2013; Tao et al., 2018). We used the SEM analysis to test our hypothesis that the $\mathrm{N}$ input-induced stimulation of SOC decomposition is associated with $\mathrm{N}$-related soil nutrients, vegetation, soil $\mathrm{C}$ storage, and the soil environment (Table 2 and Fig. 6). Higher total $\mathrm{N}$ and $\mathrm{NO}_{3}{ }^{-}$-N were observed in the $\mathrm{N}$-treated soils, both of which were positively correlated with SOC decomposition. Increased $\mathrm{N}$ availability and a decreased C:N ratio (Tables S2 and S3) stimulates the microbes to produce more C-degrading enzymes relative to the N-degrading enzymes, further accelerating SOC decomposition (Taylor et al., 1989; Allison and Vitousek, 2005). N-induced plant growth increased C input and stimulated SOC formation through soil-root interactions, indicating that root exudation leads to rhizosphere priming effects on SOC decomposition (Kuzyakov et al., 2000; Dijkstra and Cheng, 2007). Our results suggest that $\mathrm{N}$ input accelerates SOC decomposition through higher plant biomass and soil C storage. Higher SOC contents increase SOC decomposition according to the kinetic model of SOC decomposition (Fang et al., 2019). Meanwhile, N-related increases in MBC also played an important role in stimulating SOC decomposition. $\mathrm{N}$ inputs alter the microbial allocation to enzyme production, thereby affecting soil C cycling (Guan et al., 2019). We observed a significant positive correlation between MBC and SOC decomposition throughout the incubation period (Fig. 8), supporting the key role of the microbial population in SOC decomposition (Treseder, 2008; Min et al., 2011). Some studies have illustrated limited SOC decomposition due to high soil EC or salinity (Liu et al., 2017; Qu et al., 2019), stemming from lower plant productivity and microbial abundances (Setia et al., 2013; 
a)

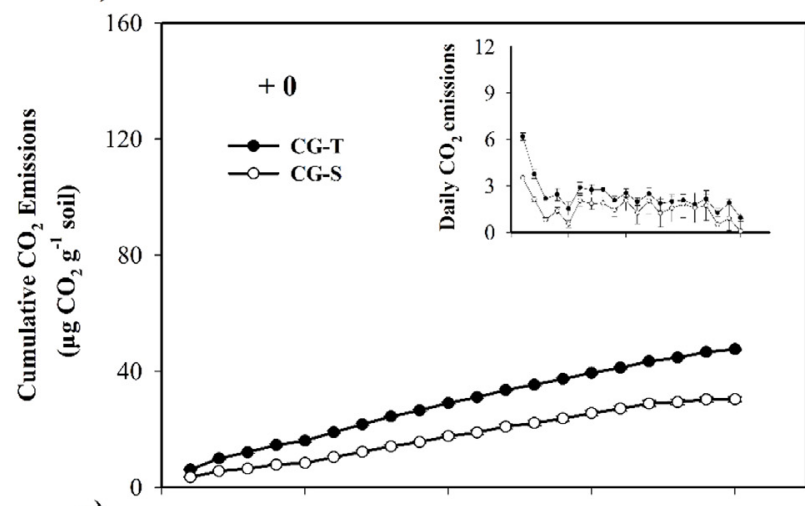

c)

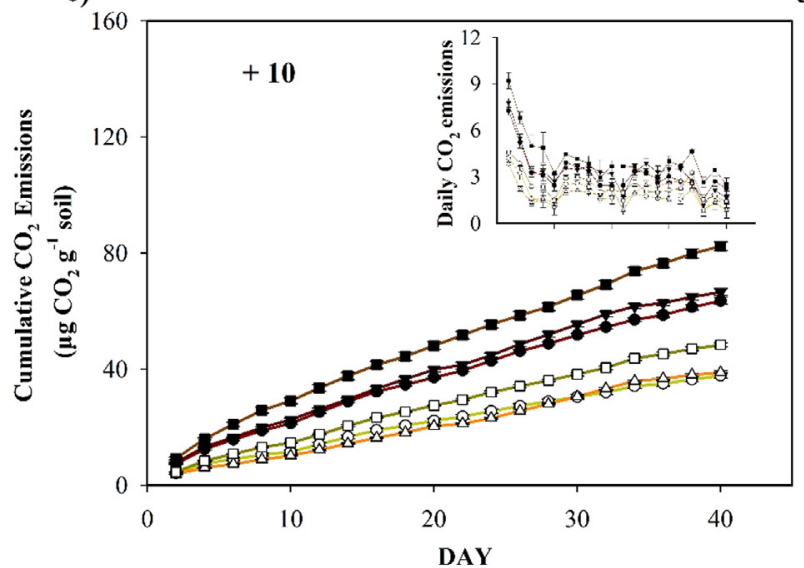

b)

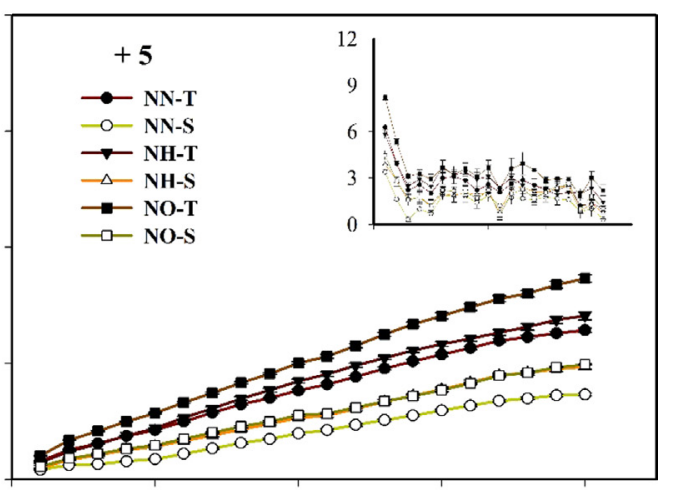

d)

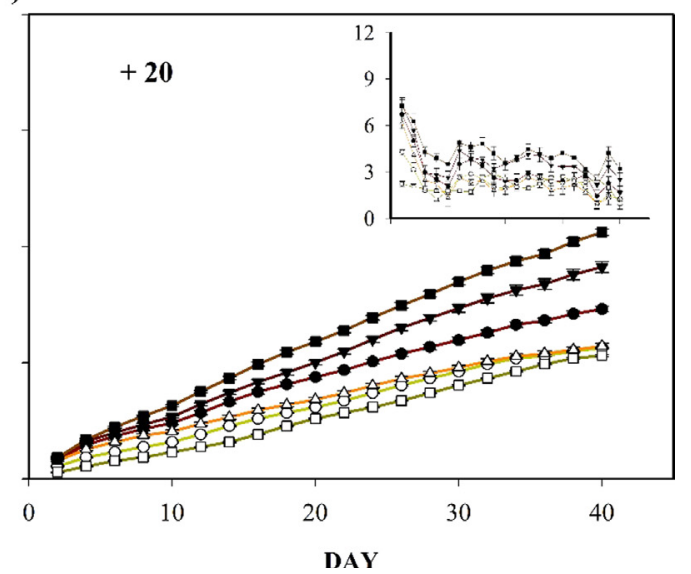

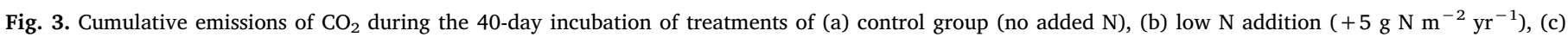

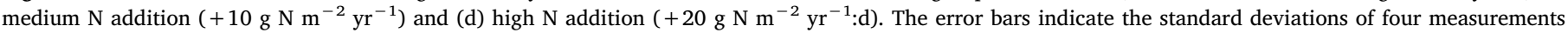

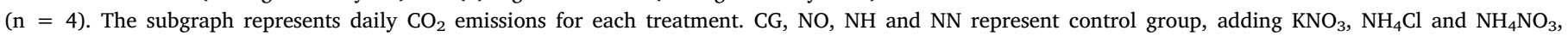
respectively. T and S represent topsoil $(0-10 \mathrm{~cm})$ and subsoil $(10-20 \mathrm{~cm})$, respectively.

Belleveau et al., 2015). We observed a negative correlation between SOC decomposition and EC (Table 2 and Fig. 6), suggesting that $\mathrm{N}$ input alleviates soil salinization via plant growth stimulation (Guan et al., 2019) and accelerated soil C losses in the coastal wetlands.

\subsection{Different responses of SOC decomposition to the dominant-form $N$ input}

Prior work has shown that the form of $\mathrm{N}$ input affects soil $\mathrm{C} \mathrm{mi-}$ neralization via biological (enzyme activities) and chemical $(\mathrm{pH})$ changes (Evans et al., 2008; Min et al., 2011). Min et al. (2011) reported neutralizing effects of $\mathrm{N}$ input on soil $\mathrm{pH}$ in alkaline soil, consistent with our results from the topsoil. Therefore, we assume SOC decomposition responds to the dominant-form $\mathrm{N}$ through $\mathrm{N}$-induced increases in the vegetation, soil $\mathrm{C}$ storage, and microbial function. Puri and Ashman (1999) found that microorganisms prefer $\mathrm{NH}_{4}{ }^{+}-\mathrm{N}$ over $\mathrm{NO}_{3}{ }^{-}-\mathrm{N}$ because of the low energy costs, indicating higher SOC decomposition rates with $\mathrm{NH}_{4}{ }^{+}-\mathrm{N}$ input. We did not find a strong correlation between $\mathrm{NH}_{4}{ }^{+}-\mathrm{N}$ and SOC decomposition, but $\mathrm{NO}_{3}{ }^{-}-\mathrm{N}$ had a significant positive correlation with SOC decomposition. NO input had the greatest effects on soil $\mathrm{NO}_{3}{ }^{-}-\mathrm{N}$ and SOC decomposition (compared to the NN- and NH-treated soils) (Fig. 5). Perhaps, $\mathrm{NO}_{3}{ }^{-}-\mathrm{N}$ had a stronger fertilization effect on plant growth than $\mathrm{NH}_{4}{ }^{+}-\mathrm{N}$, and the effect increased with the N supply level (Guan et al., 2019). The highest SOC was also observed in the NO-treated soil (Tables S2 and S3). The kinetic model of SOC decomposition suggests that NO input more easily decomposes SOC relative to $\mathrm{NN}$ and $\mathrm{NH}$, which contributes to the higher SOC contents. Increased MBC was observed under $\mathrm{N}$ input and was related to the microbial population and structure. High MBC in the
NO-treated soils provides evidence for the strongest stimulation of SOC decomposition among the dominant $\mathrm{N}$ chemical forms. NO input resulted in a microbial shift from fungal to bacterial (Allison et al., 2009), with an increase in SOC decomposition (Six et al., 2006). A prior shortterm $\mathrm{N}$ input experiment also reported positive effects of $\mathrm{NH}_{4}^{+}$on the ammonia-oxidizing bacteria (AOB) and a role for AOB in nitrification (Ying et al., 2017). This may explain the lower allocation of microbial activities in SOC decomposition compared to the $\mathrm{NO}_{3}{ }^{-}-\mathrm{N}$ soil.

\subsection{Implications for soil $C$ balance in the coastal wetlands}

Nutrient enrichment, a global problem in coastal ecosystems (Canfield et al. 2010), can lead to salt marsh loss (Deegan et al. 2012) and C cycle regulation (Min et al. 2011). Along with sea-level rise, nutrient loading results in variable soil properties and $\mathrm{C}$ exchange between the soil and atmosphere. We found higher SOC decomposition rates in the N-treated soils, with increases of $41.6 \%$ and $37.7 \%$ in topsoil and subsoil (Fig. 5), respectively. This indicates an increased $\mathrm{C}$ pool function driven by $\mathrm{N}$ input. However, continuous $\mathrm{N}$ input increased the vegetation productivity and fixed more $\mathrm{C}$ from the atmosphere into the soil, thereby acting as a $\mathrm{C}$ sink. Consistent with prior work (Liu et al. 2017), $\mathrm{N}$ input played an important but complex role in regulating the soil $\mathrm{C}$ dynamics of the coastal wetlands, interacting with the vegetation, microbial activity, and soil environment. Therefore, a better understanding of the feedback processes of $\mathrm{N}$ deposition and $\mathrm{C}$ dynamics in the coastal wetlands requires more empirical studies (Morillas et al. 2015). Moreover, forced factors, such as the $\mathrm{N}$ input forms and levels, experiment duration, and the soil depth, may moderate the SOC decomposition response. Nevertheless, the effects of 
a)
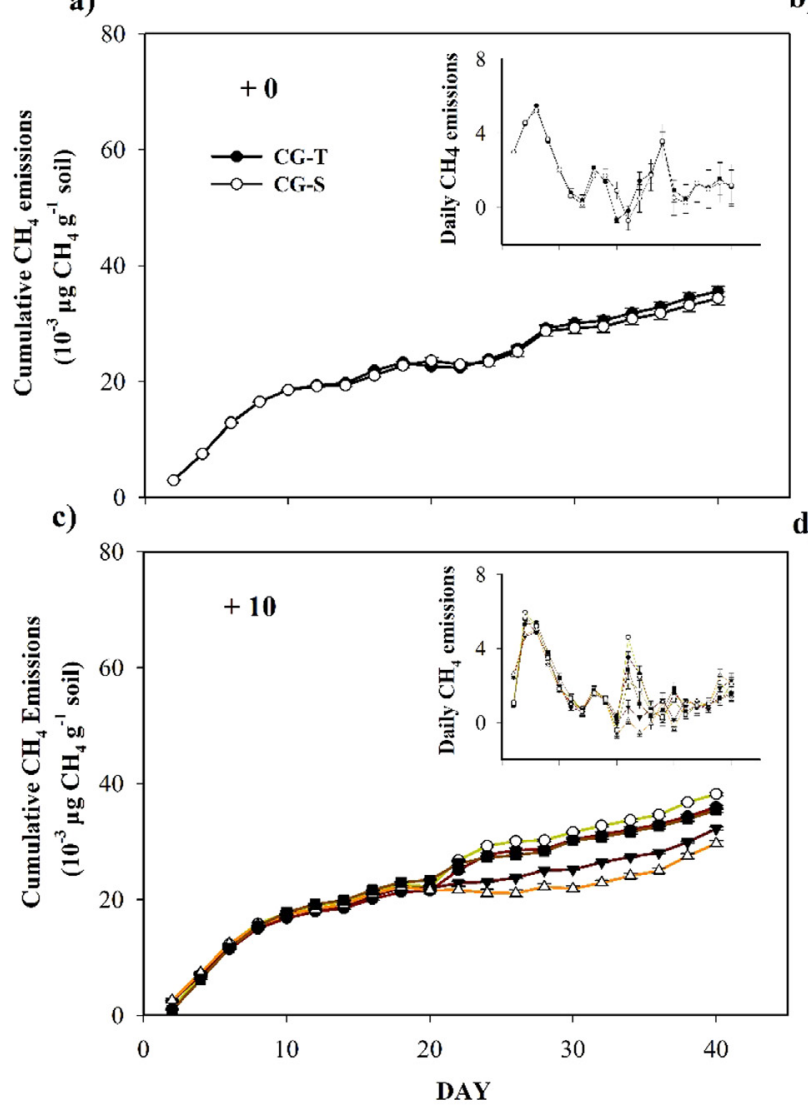

b)

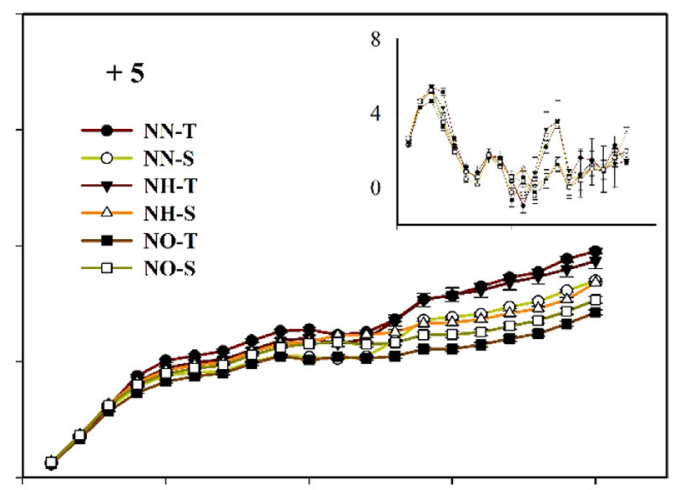

d)

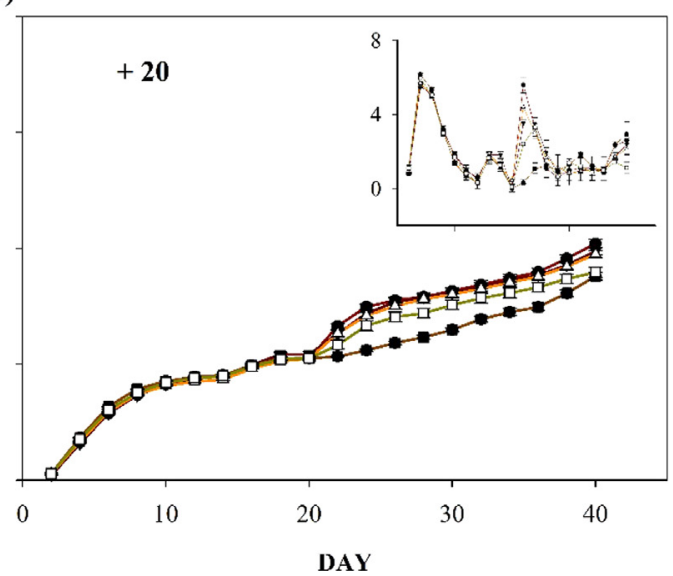

Fig. 4. Cumulative emissions of $\mathrm{CH}_{4}$ during the 40-day incubation of treatments of (a) control group (no added $\mathrm{N}$ ), ((b) low $\mathrm{N}$ addition $\left(+5 \mathrm{~g} \mathrm{~N} \mathrm{~m}^{-2} \mathrm{yr}^{-1}\right)$, (c) medium $\mathrm{N}$ addition $\left(+10 \mathrm{~g} \mathrm{~N} \mathrm{~m}^{-2} \mathrm{yr}^{-1}\right)$ and (d) high $\mathrm{N}$ addition $\left(+20 \mathrm{~g} \mathrm{~N} \mathrm{~m}^{-2} \mathrm{yr}^{-1}: \mathrm{d}\right)$. The error bars indicate the standard deviations of four measurements ( $\mathrm{n}=4$ ). The subgraph represents daily $\mathrm{CH}_{4}$ emissions for each treatment. CG, NO, $\mathrm{NH}$ and $\mathrm{NN}$ represent control group, adding $\mathrm{KNO}_{3}, \mathrm{NH}_{4} \mathrm{Cl}$ and $\mathrm{NH}_{4} \mathrm{NO}_{3}$, respectively. $\mathrm{T}$ and $\mathrm{S}$ represent topsoil $(0-10 \mathrm{~cm})$ and subsoil $(10-20 \mathrm{~cm})$, respectively.

different $\mathrm{N}$ supply forms and levels on SOC decomposition was demonstrated in this study, with implications for $\mathrm{C}$ sequestration in coastal wetlands.

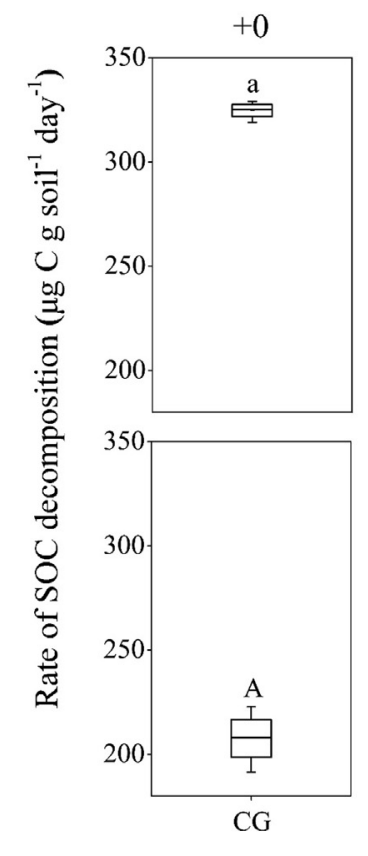

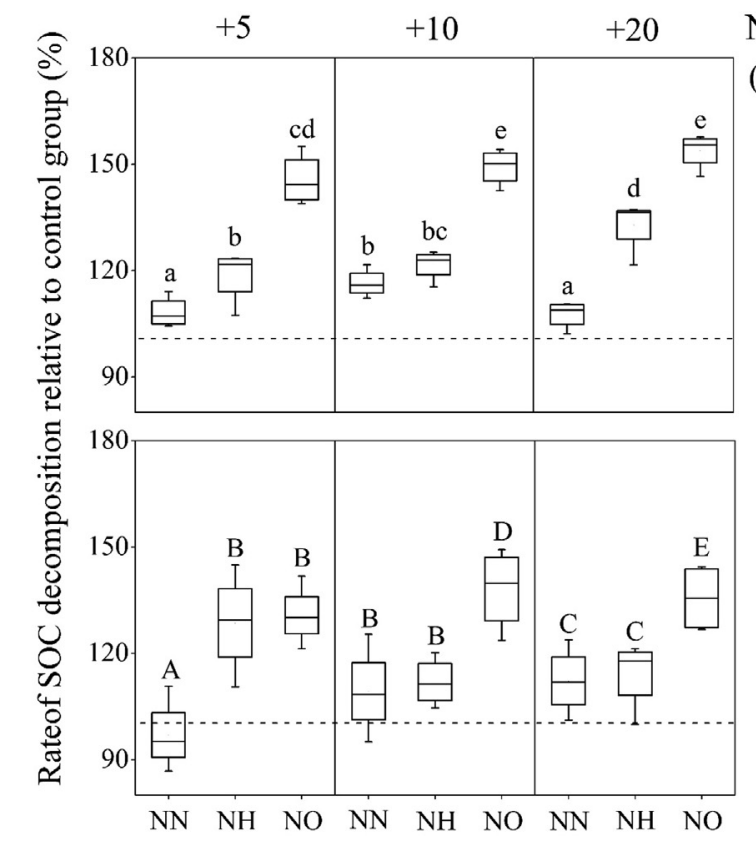

\subsection{Limitations}

Factors that may have interfered with the experiment are listed here. First, removing plants may create uncertainty in the experiment results. A previous study reported a rhizosphere priming effect, where
$\mathrm{N}$ treatments $\left(\mathrm{gN} \mathrm{m}^{-2} \mathrm{yr}^{-1}\right)$

Topsoil

Subsoil
Fig. 5. Box plots (showing the median, surrounded by a $50 \%$ quantile box and $100 \%$ quantile whiskers) of the rate of soil organic carbon decomposition (SOCD) during 40day incubation, relative to the control group, for each nitrogen $(\mathrm{N})$ chemical form, level and soil type. CG, NO, NH and NN represent control group, adding $\mathrm{KNO}_{3}$, $\mathrm{NH}_{4} \mathrm{Cl}$ and $\mathrm{NH}_{4} \mathrm{NO}_{3}$, respectively. $+0,+5$, +10 and +20 represent no $\mathrm{N}$ input, adding 5, 10 and $20 \mathrm{~g} \mathrm{~N} \mathrm{~m}^{-2} \mathrm{yr}^{-1}$, respectively. Different lower case and upper case letters represent a highly significant difference for topsoil and subsoil $(p<0.05)$, respectively. 
Table 2

Pearson correlation coefficients (r) between plant biomass, soil properties and soil organic carbon decomposition in incubation.

\begin{tabular}{|c|c|c|c|c|c|c|c|c|c|c|c|}
\hline & SOCD & $\mathrm{MBC}$ & $\mathrm{TC}$ & SOC & DOC & $\mathrm{TN}$ & $\mathrm{NH}_{4}{ }^{+}-\mathrm{N}$ & $\mathrm{NO}_{3}{ }^{-}-\mathrm{N}$ & $\mathrm{pH}$ & $\mathrm{EC}$ & $\mathrm{PB}$ \\
\hline SOCD & 1 & $0.46^{* *}$ & $0.340^{*}$ & $0.670^{* *}$ & -0.184 & $0.714^{* *}$ & 0.119 & $0.694^{* *}$ & $0.485^{* *}$ & $-0.401^{* *}$ & $0.732^{* * *}$ \\
\hline $\mathrm{MBC}$ & & 1 & $0.347^{*}$ & $0.483^{* *}$ & $-0.336^{*}$ & $0.383^{* *}$ & 0.030 & $0.539 * *$ & $0.303^{*}$ & $-0.462^{* *}$ & $0.286^{*}$ \\
\hline $\mathrm{TC}$ & & & 1 & $0.314 *$ & $-0.279^{*}$ & $0.616^{* *}$ & -0.023 & $0.663^{* *}$ & -0.013 & $-0.355^{*}$ & 0.039 \\
\hline SOC & & & & 1 & -0.022 & $0.416^{* *}$ & -0.249 & $0.399^{* *}$ & $0.575^{* * *}$ & 0.158 & $0.506^{* *}$ \\
\hline DOC & & & & & 1 & -0.062 & 0.163 & -0.256 & $-0.392 *$ & $0.509 * *$ & -0.024 \\
\hline $\mathrm{TN}$ & & & & & & 1 & 0.08 & $0.829 * *$ & 0.072 & 0.076 & $0.499^{* * *}$ \\
\hline $\mathrm{NH}_{4}{ }^{+}-\mathrm{N}$ & & & & & & & 1 & $0.355^{*}$ & -0.213 & 0.228 & 0.046 \\
\hline $\mathrm{NO}_{3}{ }^{-}-\mathrm{N}$ & & & & & & & & 1 & 0.190 & -0.010 & $0.400^{* * *}$ \\
\hline $\mathrm{pH}$ & & & & & & & & & 1 & -0.070 & $0.334^{*}$ \\
\hline $\mathrm{EC}$ & & & & & & & & & & 1 & $-0.414^{* *}$ \\
\hline PB & & & & & & & & & & & 1 \\
\hline
\end{tabular}

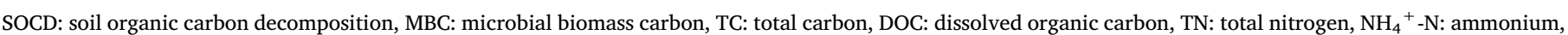
$\mathrm{NO}_{3}{ }^{-}-\mathrm{N}$ : nitrate, EC: electrical conductivity, PB: plant biomass. Significant correlations marked in bold, $\mathrm{n}=5$, where $* * p<0.01, * p<0.05$.

interactions between the soil and plant roots accelerate SOC decomposition (Dijkstra and Cheng, 2007). Increased N availability stimulated soil C loss with a higher rate of SOC decomposition and fixed more $\mathrm{C}$ into the plants and the soil, acting as a driver of $\mathrm{C}$ sequestration. Therefore, more field experiments, involving the soil, plants, and their interactions, are required to evaluate the role of $\mathrm{N}$ input on the soil $\mathrm{C}$ balance. Second, the soil salinity (Gao et al., 2019) and drying-rewetting frequency (Morillas et al. 2015) moderates the response of SOC decomposition to $\mathrm{N}$ input. This study examined only the forms and levels of $\mathrm{N}$ input and controlled the potential effects of soil salinity and water conditions. Long-term coupling experiments are required for more meaningful results. Furthermore, $\mathrm{N}$ input is a regulatory factor of $\mathrm{CH}_{4}$ oxidation and may enhance $\mathrm{CH}_{4}$ emission from the soils and sediments into the atmosphere (Bodelier \& Laanbroek 2004). We reported variability in the $\mathrm{CH}_{4}$ emissions of the different treatments but lack an empirical explanation of this phenomenon. Additional microbial experiments are required to investigate the responses of bacterial and methanotrophic communities to different chemical forms and levels of $\mathrm{N}$ input.

\section{Conclusions}

Our results suggest that six years of $\mathrm{N}$ input accelerated the SOC decomposition in the YRD coastal wetland. This was related to N-induced shifts in the soil properties and plant growth. Increased $\mathrm{N}$ availability significantly stimulated plant growth, increased soil C
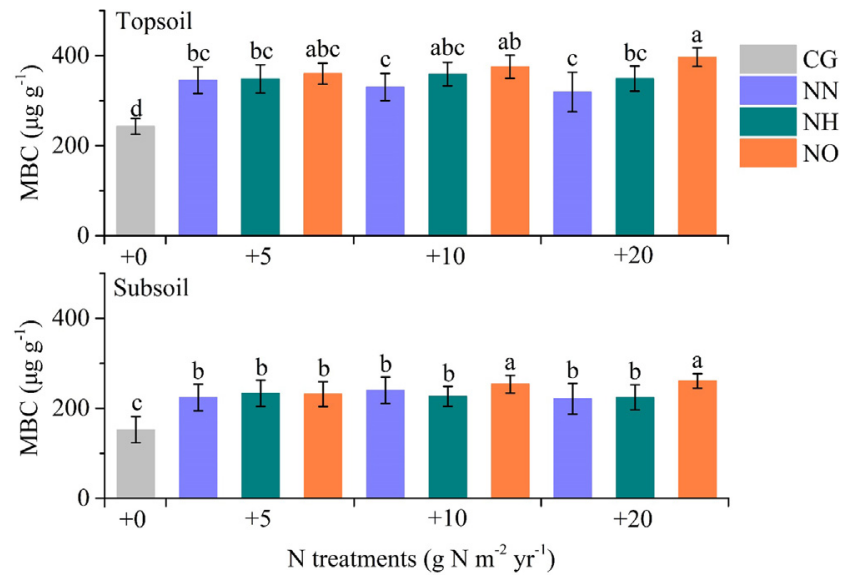

Fig. 7. Effects of nitrogen (N) input on the microbial biomass carbon (MBC) of all nitrogen-addition treatments in topsoil $(0-10 \mathrm{~cm})$ and subsoil $(10-20 \mathrm{~cm})$, respectively. The bar graphs represent average MBC for day 10, 2030 and 40. Different lower case letters represent a highly significant difference for average MBC $(p<0.05)$. CG, NO, NH and NN represent control group, adding $\mathrm{KNO}_{3}$, $\mathrm{NH}_{4} \mathrm{Cl}$ and $\mathrm{NH}_{4} \mathrm{NO}_{3}$, respectively. $+0,+5,+10$ and +20 represent no $\mathrm{N}$ input, adding 5, 10 and $20 \mathrm{~g} \mathrm{~N} \mathrm{~m}^{-2} \mathrm{yr}^{-1}$, respectively.

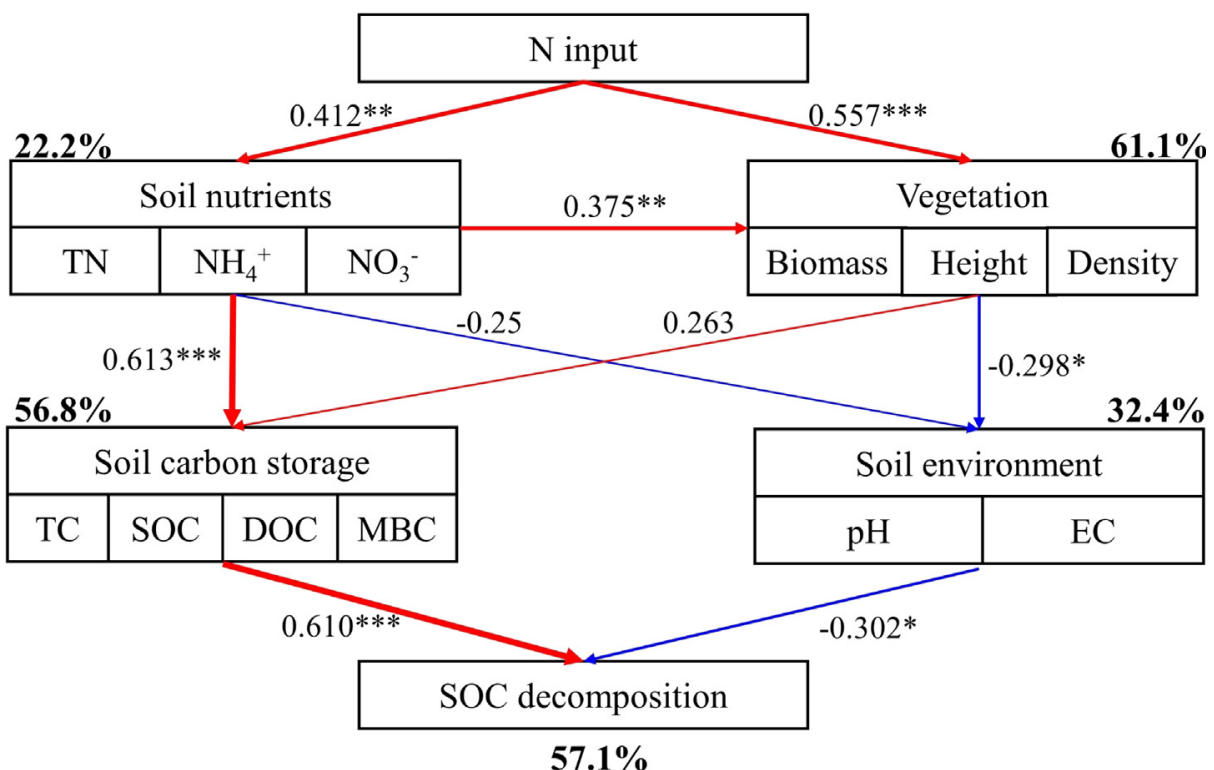

Fig. 6. Structural equation model (SEM) analysis describing the effects of soil nutrients, vegetation, soil carbon storage, and soil environment on soil organic carbon decomposition under nitrogen input. TN: total nitrogen, $\mathrm{NH}_{4}{ }^{+}-\mathrm{N}$ : ammonium, $\mathrm{NO}_{3}{ }^{-}-\mathrm{N}$ : nitrate, TC: total carbon, SOC: soil organic carbon, DOC: dissolved organic carbon, MBC: microbial biomass carbon, EC: electrical conductivity. Path coefficients (correlation coefficients) along arrows are standardized by the mean of each parameter. Numbers on the arrows are standardized direct path coefficients. Red arrow lines indicate positive effects, and blue arrow lines indicate negative effects. The width of the arrows is proportional to the strength of the relationship, and the numbers adjacent to arrows are standardized path coefficients. Percentages close to variables refer to the variance accounted for by the model $\left(\mathrm{R}^{2}\right)$. * $p<0.05,{ }^{* *} p<0.01, * * * p<0.001$. 
a)

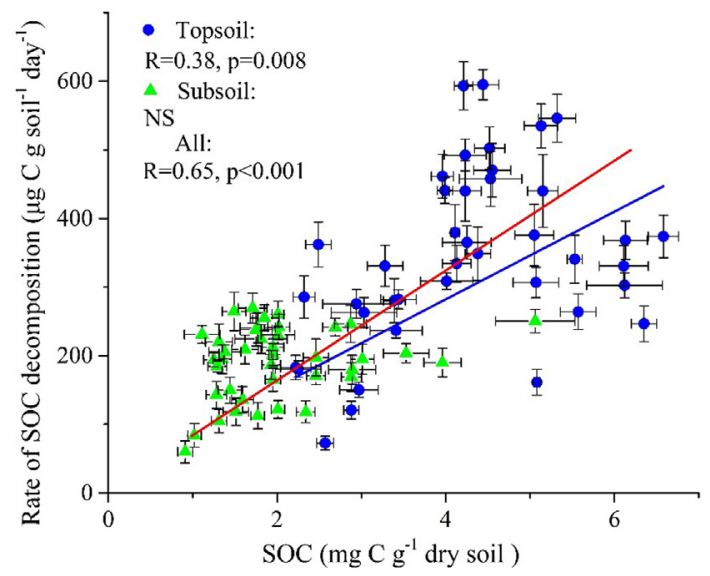

b)

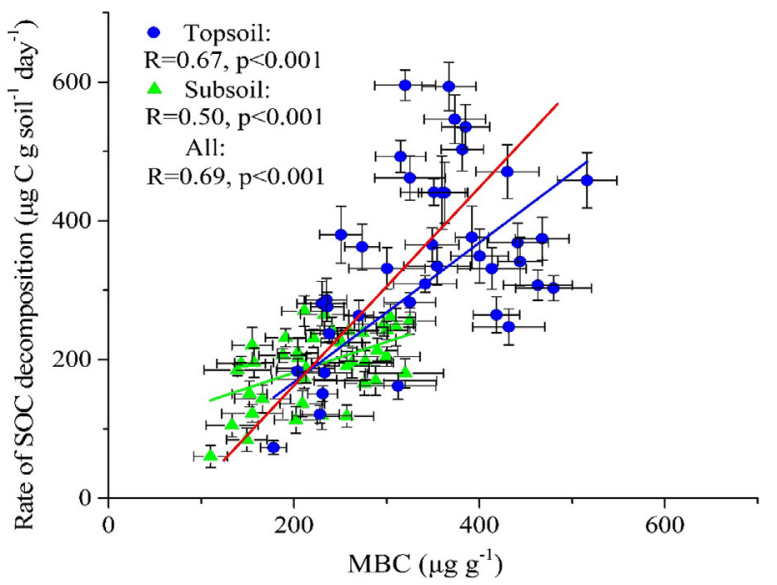

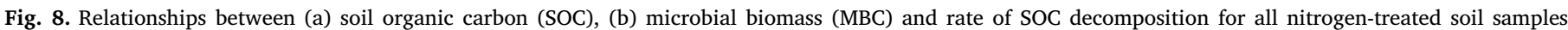
(topsoil: 0-10 cm; subsoil: 10-20 cm) in four stages of incubation (day 10, 20, 30 and 40). Significance was set at $p<0.05$.

storage, and decreased the soil EC. SOC decomposition was positively associated with SOC, $\mathrm{MBC}$, and $\mathrm{NO}_{3}{ }^{-}-\mathrm{N}$, and negatively correlated with soil EC. The NO-treated soil had the highest rate of SOC decomposition. Differences in the stimulatory effects of the dominant-form $\mathrm{N}$ inputs increased with increasing $\mathrm{N}$ levels ( $\mathrm{NO}>\mathrm{NH}>\mathrm{NN}$ ), and the optimal level of $\mathrm{N}$ input to maximize SOC decomposition was $\mathrm{N}$-form dependent. MBC helped to explain differences in SOC decomposition among the different $\mathrm{N}$-form soil samples during the incubation period. From the SEM analysis, we conclude that $\mathrm{N}$ input stimulates SOC decomposition via effects on the soil nutrients, vegetation, soil C storage, and soil environment.

\section{Declaration of Competing Interest}

The authors declare that they have no known competing financial interests or personal relationships that could have appeared to influence the work reported in this paper.

\section{Acknowledgements}

This research was funded by the Strategic Priority Research Program of the Chinese Academy of Sciences (XDA23050202) and the National Natural Science Foundation of China (41671089). We are grateful for the support from Yellow River Delta Ecological Research Station of Coastal Wetland, CAS.

\section{Appendix A. Supplementary material}

Supplementary data to this article can be found online at https:// doi.org/10.1016/j.catena.2020.104672.

\section{References}

Allison, S., Vitousek, P., 2005. Responses of extracellular enzymes to simple and complex nutrient inputs. Soil Biol. Biochem. 37, 937-944. https://doi.org/10.1016/j.soilbio. 2004.09.014.

Allison, S.D., LeBauer, D.S., Ofrecio, M.R., Reyes, R., Ta, A.-M., Tran, T.M., 2009. Low levels of nitrogen addition stimulate decomposition by boreal forest fungi. Soil Biol. Biochem. 41, 293-302. https://doi.org/10.1016/j.soilbio.2008.10.032.

Barbier, E.B., Hacker, S.D., Kennedy, C., Koch, E.W., Stier, A.C., Silliman, B.R., 2011. The value of estuarine and coastal ecosystem services. Ecol. Monogr. 81, 169-193. https://doi.org/10.1890/10-1510.1.

Belleveau, L.J., Takekawa, J.Y., Woo, I., Turner, K.L., Barham, J.B., Takekawa, J.E., Ellings, C.S., Chin-Leo, G., 2015. Vegetation community response to tidal marsh restoration of a large river estuary. Northwest Sci. 89, 136-147. https://doi.org/10. 3955/046.089.0205.

Bodelier, P.L.E., Laanbroek, H.J., 2004. Nitrogen as a regulatory factor of methane oxidation in soils and sediments. FEMS Microbiol. Ecol. 47, 265-277. https://doi.org/
10.1016/S0168-6496(03)00304-0.

Bolinder, M.A., Kätterer, T., Andrén, O., Ericson, L., Parent, L.-E., Kirchmann, H., 2010. Long-term soil organic carbon and nitrogen dynamics in forage-based crop rotations in northern Sweden $\left(63-64^{\circ} \mathrm{N}\right)$. Agric. Ecosyst. Environ. 138, 335-342. https://doi. org/10.1016/j.agee.2010.06.009.

Bridgham, S.D., Megonigal, J.P., Keller, J.K., Bliss, N.B., Trettin, C., 2006. The carbon balance of North American wetlands. Wetlands 26, 889-916. https://doi.org/10. 1672/0277-5212(2006)26.

Brookes, P.C., Kragt, J.F., Powlson, D.S., Jenkinson, D.S., 1985. Chloroform Fumigation and the Release of Soil-Nitrogen - the Effects of Fumigation Time and Temperature. Soil Biol. Biochem. 17, 831-835. https://doi.org/10.1016/0038-0717(85)90143-9.

Canfield, D.E., Glazer, A.N., Falkowski, P.G., 2010. The evolution and future of Earth's nitrogen cycle. Science 330, 192-196. https://doi.org/10.1126/science.1186120.

Chambers, L.G., Osborne, T.Z., Reddy, K.R., 2013. Effect of salinity-altering pulsing events on soil organic carbon loss along an intertidal wetland gradient: a laboratory experiment. Biogeochemistry 115, 363-383. https://doi.org/10.1007/s10533-0139841-5.

Costanza, R., d'Arge, R., de Groot, R., Farber, S., Grasso, M., Hannon, B., Limburg, K., Naeem, S., O'Neill, R.V., Paruelo, J., Raskin, R.G., Sutton, P., van den Belt, M., 1997. The value of the world's ecosystem services and natural capital. Nature 387, 253-260. https://doi.org/10.1038/387253a0.

Cui, B.S., Yang, Q.C., Yang, Z.F., Zhang, K.J., 2009. Evaluating the ecological performance of wetland restoration in the Yellow River Delta, China. Ecol. Eng. 35, 1090-1103. https://doi.org/10.1016/j.ecoleng.2009.03.022.

Deegan, L.A., Johnson, D.S., Warren, R.S., Peterson, B.J., Fleeger, J.W., Fagherazzi, S., Wollheim, W.M., 2012. Coastal eutrophication as a driver of salt marsh loss. Nature 490, 388. https://doi.org/10.1038/nature11533.

Dijkstra, F.A., Cheng, W., 2007. Interactions between soil and tree roots accelerate longterm soil carbon decomposition. Ecol. Lett. 10, 1046-1053. https://doi.org/10.1111/ j.1461-0248.2007.01095.x.

Evans, C., Goodale, C., Caporn, S.J., Dise, N., Emmett, B., Fernandez, I., Field, C., Finflay, S.E., Lovett, G., Meesenburg, H., Moldan, F., Sheppard, L., 2008. Does elevated nitrogen deposition or ecosystem recovery from acidification drive increased dissolved organic carbon loss from upland soil? A review of evidence from field nitrogen addition experiments. Biogeochemistry 91, 13-35. https://doi.org/10.1007/s10533008-9256-x.

Fang, X.M., Zhang, X.L., Chen, F.S., Zong, Y.Y., Bu, W.S., Wan, S.Z., Luo, Y., Wang, H., 2019. Phosphorus addition alters the response of soil organic carbon decomposition to nitrogen deposition in a subtropical forest. Soil Biol. Biochem. 133, 119-128. https://doi.org/10.1016/j.soilbio.2019.03.005.

Ferrati, R., Canziani, G.A., Moreno, D.R., 2005. Esteros del Ibera: hydrometeorological and hydrological characterization. Ecol. Model. 186, 3-15. https://doi.org/10.1016/ j.ecolmodel.2005.01.021.

Freschet, G.T., Bellingham, P.J., Lyver, P.O., Bonner, K.I., Wardle, D.A., 2013. Plasticity in above- and belowground resource acquisition traits in response to single and multiple environmental factors in three tree species. Ecol. Evol. 3, 1065-1078. https://doi.org/10.1002/ece3.520.

Galloway, J.N., Townsend, A.R., Erisman, J.W., Bekunda, M., Cai, Z.C., Freney, J.R. Martinelli, L.A., Seitzinger, S.P., Sutton, M.A., 2008. Transformation of the nitrogen cycle: Recent trends, questions, and potential solutions. Science 320, 889-892. https://doi.org/10.1126/science.1136674.

Gao, Y., Sun, S.N., Xing, F., Mu, X.M., Bai, Y.G., 2019. Nitrogen addition interacted with salinity-alkalinity to modify plant diversity, microbial PLFAs and soil coupled elements: A 5-year experiment. Appl. Soil Ecol. 137, 78-86. https://doi.org/10.1016/j. apsoil.2019.01.011.

Gerdol, R., Bragazza, L., Brancaleoni, L., 2008. Heatwave 2003: high summer temperature, rather than experimental fertilization, affects vegetation and $\mathrm{CO}_{2}$ exchange in an alpine bog. New Phytol. 179, 142-154. https://doi.org/10.1111/j.1469-8137. 2008.02429.x. 
Guan, B., Xie, B.H., Yang, S.S., Hou, A.X., Chen, M., Han, G.X., 2019. Effects of five years' nitrogen deposition on soil properties and plant growth in a salinized reed wetland of the Yellow River Delta. Ecol. Eng. 136, 160-166. https://doi.org/10.1016/j.ecoleng. 2019.06.016.

Hair, J.F., Hollingsworth, C.L., Randolph, A.B., Chong, A.Y.L., 2017. An Updated and Expanded Assessment of PLS-SEM in Information Systems Research. Industrial Management \& Data Systems 117 (3), 442-458. https://doi.org/10.1108/IMDS-042016-0130.

Han, G.X., Chu, X.J., Xing, Q.H., Li, D.J., Yu, J.B., Luo, Y.Q., Wang, G.M., Mao, P.L., Rafique, R., 2015. Effects of episodic flooding on the net ecosystem $\mathrm{CO}_{2}$ exchange of a supratidal wetland in the Yellow River Delta. Journal of Geophysical ResearchBiogeosciences 120, 1506-1520. https://doi.org/10.1002/2015jg002923.

Han, G.X., Sun, B.Y., Chu, X.J., Xing, Q.H., Song, W.M., Xia, J.Y., 2018. Precipitation events reduce soil respiration in a coastal wetland based on four-year continuous field measurements. Agric. For. Meteorol. 256, 292-303. https://doi.org/10.1016/j. agrformet.2018.03.018.

Janssens, I.A., Dieleman, W., Luyssaert, S., Subke, J.-A., Reichstein, M., Ceulemans, P., Ciais, P., Dolman, A.J., Grace, J., Matteucci, G., Papale, D., Piao, S.L., Schulze, E.-D., Tang, J., Law, B.E., 2010. Reduction of forest soil respiration in response to nitrogen deposition. Nat. Geosci. 3, 315-322. https://doi.org/10.1038/ngeo844.

Knorr, M., Frey, S.D., Curtis, P.S., 2005. Nitrogen additions and litter decomposition: A meta-analysis. Ecology 86, 3252-3257. https://doi.org/10.1890/05-0150.

Krupa, S.V., 2003. Effects of atmospheric ammonia (NH3) on terrestrial vegetation: a review. Environ. Pollut. 124, 179-221. https://doi.org/10.1016/s0269-7491(02) 00434-7.

Kuzyakov, Y., Friedel, J.K., Stahr, K., 2000. Review of mechanisms and quantification of priming effects. Soil Biol. Biochem. 32, 1485-1498. https://doi.org/10.1016/S00380717(00)00084-5.

Liu, J., Wu, N., Wang, H., Sun, J., Peng, B., Jiang, P., Bai, E., 2016. Nitrogen addition affects chemical compositions of plant tissues, litter and soil organic matter. Ecology 97, 1796-1806. https://doi.org/10.1890/15-1683.1.

Liu, X.J., Ruecker, A., Song, B., Xing, J., Conner, W.H., Chow, A.T., 2017. Effects of salinity and wet-dry treatments on $\mathrm{C}$ and $\mathrm{N}$ dynamics in coastal-forested wetland soils: Implications of sea level rise. Soil Biol. Biochem. 112, 56-67. https://doi.org/ 10.1016/j.soilbio.2017.04.002.

Lugato, E., Berti, A., Giardini, L., 2006. Soil organic carbon (SOC) dynamics with and without residue incorporation in relation to different nitrogen fertilisation rates. Geoderma 135, 315-321. https://doi.org/10.1016/j.geoderma.2006.01.012.

Magill, A.H., Aber, J.D., 1998. Long-term effects of experimental nitrogen additions on foliar litter decay and humus formation in forest ecosystems. Plant Soil 203, 301-311. https://doi.org/10.1023/a:1004367000041.

Manning, P., Saunders, M., Bardgett, R.D., Bonkowski, M., Bradford, M.A., Ellis, R.J., Kandeler, E., Marhan, S., Tscherko, D., 2008. Direct and indirect effects of nitrogen deposition on litter decomposition. Soil Biol. Biochem. 40, 688-698. https://doi.org/ 10.1016/j.soilbio.2007.08.023.

Marton, J., Herbert, E., Craft, C., 2012. Effects of salinity on denitrification and greenhouse gas production from laboratory-incubated tidal forest soils. Wetlands 32 , 347-357. https://doi.org/10.1007/s13157-012-0270-3.

Mavi, M.S., Marschner, P., 2012. Drying and wetting in saline and saline-sodic soils-effects on microbial activity, biomass and dissolved organic carbon. Plant Soil 355, 51-62. https://doi.org/10.1007/s11104-011-1078-2.

McKane, R.B., Johnson, L.C., Shaver, G.R., Nadelhoffer, K.J., Rastetter, E.B., Fry, B., Giblin, A.E., Kielland, K., Kwiatkowski, B.L., Laundre, J.A., Murray, G., 2002. Resource-based niches provide a basis for plant species diversity and dominance in arctic tundra. Nature 415, 68-71. https://doi.org/10.1038/415068a.

Meng, W.Q., He, M.X., Hu, B.B., Mo, X.Q., Li, H.Y., Liu, B.Q., Wang, Z.L., 2017. Status of wetlands in China: A review of extent, degradation, issues and recommendations for improvement. Ocean Coast. Manag. 146, 50-59. https://doi.org/10.1016/j. ocecoaman.2017.06.003.

Min, K., Kang, H., Lee, D., 2011. Effects of ammonium and nitrate additions on carbon mineralization in wetland soils. Soil Biol. Biochem. 43, 2461-2469. https://doi.org/ 10.1016/j.soilbio. 2011.08.019.

Mo, J., Zhang, W., Zhu, W., Gundersen, P., Fang, Y., Li, D., Wang, H., 2008. Nitrogen addition reduces soil respiration in a mature tropical forest in southern China. Glob. Change Biol. 14, 403-412. https://doi.org/10.1111/j.1365-2486.2007.01503.x.

Morillas, L., Durán, J., Rodríguez, A., Roales, J., Gallardo, A., Lovett, G.M., Groffman, P.M., 2015. Nitrogen supply modulates the effect of changes in drying-rewetting frequency on soil C and N cycling and greenhouse gas exchange. Glob. Change Biol. 21, 3854-3863. https://doi.org/10.1111/gcb.12956.

Neff, J.C., Townsend, A.R., Gleixner, G., Lehman, S.J., Turnbull, J., Bowman, W.D., 2002. Variable effects of nitrogen additions on the stability and turnover of soil carbon. Nature 419, 915-917. https://doi.org/10.1038/nature01136.

Nicol, G.W., Leininger, S., Schleper, C., Prosser, J.I., 2008. The influence of soil pH on the diversity, abundance and transcriptional activity of ammonia oxidizing archaea and bacteria. Environ. Microbiol. 10, 2966-2978. https://doi.org/10.1111/j.1462-2920. 2008.01701.x.

Poffenbarger, H.J., Sawyer, J.E., Barker, D.W., Olk, D.C., Six, J., Castellanoa, M.J., 2018. Legacy effects of long-term nitrogen fertilizer application on the fate of nitrogen fertilizer inputs in continuous maize. Agric. Ecosyst. Environ. 265, 544-555. https:// doi.org/10.1016/j.agee.2018.07.005.

Puri, G., Ashman, M.R., 1999. Microbial immobilization of N-15-labelled ammonium and nitrate in a temperate woodland soil. Soil Biol. Biochem. 31, 929-931. https://doi. org/10.1016/s0038-0717(98)00172-2.

Qu, W.D., Li, J.Y., Han, G.X., Wu, H.T., Song, W.M., Zhang, X.S., 2019. Effect of salinity on the decomposition of soil organic carbon in a tidal wetland. J. Soils Sediments 19, 609-617. https://doi.org/10.1007/s11368-018-2096-y.
Reay, D.S., Dentener, F., Smith, P., Grace, J., Feely, R.A., 2008. Global nitrogen deposition and carbon sinks. Nat. Geosci. 1, 430-437. https://doi.org/10.1038/ngeo230.

Reich, P.B., Hobbie, S.E., 2013. Decade-long soil nitrogen constraint on the $\mathrm{CO}_{2}$ fertilization of plant biomass. Nat. Clim. Change 3, 278-282. https://doi.org/10.1038/ nclimate1694.

Robertson, G.P., Wedin, D., Groffman, P.M., Blair, J.M., Holland, E.A., Nadelhoffer, K.J., Harris, D., 1999. Soil carbon and nitrogen availability: nitrogen mineralization, nitrification, and soil respiration potentials. In: Robertson, G.P., Coleman, D.C., Bledsoe, C.S., Sollins, P. (Eds.), Standard Soil Methods for Long-Term Ecological Research. Oxford University Press, New York.

Roem, W.J., Berendse, F., 2000. Soil acidity and nutrient supply ratio as possible factors determining changes in plant species diversity in grassland and heathland communities. Biol. Conserv. 92, 151-161. https://doi.org/10.1016/s0006-3207(99) 00049-x.

Setia, R., Gottschalk, P., Smith, P., Marschner, P., Baldock, J., Setia, D., Smith, J., 2013. Soil salinity decreases global soil organic carbon stocks. Science of Total Environment 465, 267-272. https://doi.org/10.1016/j.scitotenv.2012.08.028.

Shaygan, M., Mulligan, D., Baumgartl, T., 2018. The potential of three halophytes (Tecticornia pergranulata, Sclerolaena longicuspis, and Frankenia serpyllifolia) for the rehabilitation of brine-affected soils. Land Degrad. Dev. 29 (6), 2002-2014. https://doi.org/10.1002/ldr.2954.

Sims, L., Pastor, J., Lee, T., Dewey, B., 2012. Nitrogen, phosphorus and light effects on growth and allocation of biomass and nutrients in wild rice. Oecologia 170, 65-76. https://doi.org/10.1007/s00442-012-2296-x.

Six, J., Frey, S.D., Thiet, R.K., Batten, K.M., 2006. Bacterial and fungal contributions to carbon sequestration in agroecosystems. Soil Sci. Soc. Am. J. 70, 555-569. https:// doi.org/10.2136/sssaj2004.0347.

Sjoberg, G., Knicker, H., Nilsson, S.I., Berggren, D., 2004. Impact of long-term N fertilization on the structural composition of spruce litter and mor humus. Soil Biol. Biochem. 36, 609-618. https://doi.org/10.1016/j.soilbio.2003.11.006.

Song, M.H., Guo, Y., Yu, F.H., Zhang, X.Z., Cao, G.M., Cornelissen, J.H.C., 2018. Shifts in priming partly explain impacts of long-term nitrogen input in different chemical forms on soil organic carbon storage. Glob. Change Biol. 24, 4160-4172. https://doi. org/10.1111/gcb.14304.

Tao, B., Song, C., Guo, Y., 2013. Short-term Effects of Nitrogen Additions and Increased Temperature on Wetland Soil Respiration, Sanjiang Plain, China. Wetlands 33, 727-736. https://doi.org/10.1007/s13157-013-0432-y.

Tao, B.X., Liu, C.Y., Zhang, B.H., Dong, J., 2018. Effects of inorganic and organic nitrogen additions on $\mathrm{CO}_{2}$ emissions in the coastal wetlands of the Yellow River Delta, China. Atmos. Environ. 185, 159-167. https://doi.org/10.1016/j.atmosenv.2018.05.009.

Taylor, B.R., Parkinson, D., Parsons, W.F.J., 1989. Nitrogen and lignin content as predictors of litter decay-rates - a microcosm test. Ecology 70, 97-104. https://doi.org/ $10.2307 / 1938416$.

Tian, J., Dungait, J., Lu, X.K., Yang, Y.F., Hartley, L.P., Zhang, W., Mo, J.M., Yu, G.R., Zhou, J.Z., Kuzyakov, Y., 2019. Long-term nitrogen addition modifies microbial composition and functions for slow carbon cycling and increased sequestration in tropical forest soil. Glob. Change Biol. 25, 3267-3281. https://doi.org/10.1111/gcb. 14750.

Treseder, K.K., 2008. Nitrogen additions and microbial biomass: a meta-analysis of ecosystem studies. Ecol. Lett. 11, 1111-1120. https://doi.org/10.1111/j.1461-0248. 2008.01230.x.

Tu, L., Hu, T., Zhang, J., Li, X., Hu, H., Liu, L., Xiao, Y., 2013. Nitrogen addition stimulates different components of soil respiration in a subtropical bamboo ecosystem. Soil Biol. Biochem. 58, 255-264. https://doi.org/10.1016/j.soilbio.2012.12.005.

van der Heijden, M.G.A., Bardgett, R.D., van Straalen, N.M., 2008. The unseen majority: soil microbes as drivers of plant diversity and productivity in terrestrial ecosystems. Ecol. Lett. 11, 296-310. https://doi.org/10.1111/j.1461-0248.2007.01139.x.

Vitousek, P., 1982. Nutrient cycling and nutrient use efficiency. Am. Nat. 119, 553-572. https://doi.org/10.1086/283931.

Wang, J., Gao, Y., Zhang, Y., Yang, J., Smith, M.D., Knapp, A.K., Eissenstat, D.M., Han, X., 2019a. Asymmetry in above- and belowground productivity responses to N addition in a semi-arid temperate steppe. Glob. Change Biol. 25, 2958-2969. https://doi.org/ 10.1111/gcb.14719.

Wang, Q., Tian, P., Liu, S., Sun, T., 2017. Inhibition effects of $\mathrm{N}$ deposition on soil organic carbon decomposition was mediated by $\mathrm{N}$ types and soil nematode in a temperate forest. Appl. Soil Ecol. 120, 105-110. https://doi.org/10.1016/j.apsoil.2017.08.005.

Wang, Q.K., Chen, L.C., Yang, Q.P., Sun, T., Li, C.M., 2019b. Different effects of single versus repeated additions of glucose on the soil organic carbon turnover in a temperate forest receiving long-term N addition. Geoderma 341, 59-67. https://doi.org/ 10.1016/j.geoderma.2019.01.032.

Wang, Q.K., Liu, S.G., Wang, Y.P., Tian, P., Sun, T., 2018. Influences of N deposition on soil microbial respiration and its temperature sensitivity depend on $\mathrm{N}$ type in a temperate forest. Agric. For. Meteorol. 260, 240-246. https://doi.org/10.1016/j. agrformet.2018.06.018.

Wong, K.K., 2013. Partial Least Squares Structural Equation Modeling (PLS-SEM) Techniques Using SmartPLS. Marketing Bulletin 24, 1-32.

Ying, J., Li, X., Wang, N., Lan, Z., He, J., Bai, Y., 2017. Contrasting effects of nitrogen forms and soil $\mathrm{pH}$ on ammonia oxidizing microorganisms and their responses to long term nitrogen fertilization in a typical steppe ecosystem. Soil Biol. Biochem. 107, 10-18. https://doi.org/10.1016/j.soilbio.2016.12.023.

Yu, J.B., Ning, K., Li, Y.Z., Du, Y.S., Han, G.X., Xing, Q.H., Wu, H.F., Wang, G.M., Gao, Y.J., 2014. Wet and dry atmospheric depositions of inorganic nitrogen during plant growing season in the coastal zone of Yellow River Delta. Sci. World J. https://doi. org/10.1155/2014/949213.

Zhang, T.T., Zeng, S.L., Gao, Y., Ouyang, Z.T., Li, B., Fang, C.M., Zhao, B., 2011. Assessing impact of land uses on land salinization in the Yellow River Delta, China using an 
integrated and spatial statistical model. Land Use Policy 28, 857-866. https://doi. org/10.1016/j.landusepol.2011.03.002.

Zhou, L.Y., Zhou, X.H., Zhang, B.C., Lu, M., Luo, Y.Q., Liu, L.L., Li, B., 2014. Different responses of soil respiration and its components to nitrogen addition among biomes: a meta-analysis. Glob. Change Biol. 20, 2332-2343. https://doi.org/10.1111/gcb.
12490.

Zhou, Y.P., Bastida, F., Zhou, B., Sun, Y.F., Gu, T., Li, S.Q., Li, Y.K., 2020. Soil fertility and crop production are fostered by micro-nano bubble irrigation with associated changes in soil bacterial community. Soil Biol. Biochem. 141, 107663. https://doi.org/10. 1016/j.soilbio.2019.107663. 